\title{
RADIATION RESEARCH
}

EDITOR-IN-CHIEF: R. J. M. FRY

Volume 116, 1988

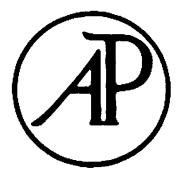

ACADEMIC PRESS, INC.

San Diego New York Boston

London Sydney Tokyo Toronto 


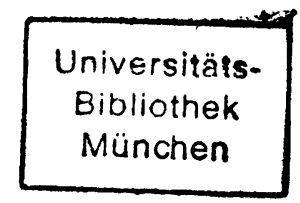

Copyright (C) 1988 by Academic Press, Inc.

All rights reserved

No part of this publication may be reproduced or transmitted in any form or by any means, electronic or mechanical, including photocopy, recording, or any information storage and retrieval system, without permission in writing from the copyright owner.

The appearance of the code at the bottom of the first page of an article in this journal indicates the copyright owner's consent that copies of the article may be made for personal or internal use, or for the personal or internal use of specific clients. This consent is given on the condition, however, that the copier pay the stated per copy fee through the Copyright Clearance Center, Inc. (27 Congress Street, Salem, Massachusetts 01970), for copying beyond that permitted by Sections 107 or 108 of the U. S. Copyright Law. This consent does not extend to other kinds of copying, such as copying for general distribution, for advertising or promotional purposes, for creating new collective works, or for resale. Copy fees for pre-1988 articles are as shown on the article title pages; if no fee code appears on the title page, the copy fee is the same as for current articles.

$0033-7587 / 88 \$ 3.00$ 


\section{OFFICIAL ORGAN OF THE RADIATION RESEARCH SOCIETY}

Editor-in-Chief: R. J. M. FRY, Biology Division, Oak Ridge National Laboratory, P.O. Box 2009, Oak Ridge, Tennessee 37831-8077

Managing Editor: MARTHA EDINGTON, University of Tennessee-Oak Ridge Graduate School of Biomedical Sciences, Biology Division, Oak Ridge National Laboratory, P.O. Box 2009, Oak Ridge, Tennessee 37831-8077

\section{ASSOCIATE EDITORS}

G. E. ADAMS, Medical Research Council, Harwell, Didcot, Oxfordshire, England

K. K. ANG, University of Texas

J. S. BEDFORD, Colorado State University

C. A. CAIN, University of Illinois

J. DENEKAMP, Gray Laboratory, Northwood, Middlesex, England

W. C. DEWEY, University of California, San Francisco

R. E. DURAND, British Columbia Cancer Research Center, Vancouver, Canada

E. R. EPP, Massachusetts General Hospital

C. R. GEARD, Columbia University

E. L. GILLETTE, Colorado State University

D. J. GRDINA, Argonne National Laboratory

R. N. HAMM, Oak Ridge National Laboratory
F. W. HETZEL, Henry Ford Hospital and Oakland University

M. Z. HOFFMAN, Boston University

L. E. HOPWOOD, Medical College of Wisconsin

R. E. KRISCH, University of Pennsylvania

J. B. MITCHELL, National Cancer Institute

J. L. REDPATH, University of California, Irvine

M. A. J. RODGERS, Bowling Green State University

W. SCHIMMERLING, Lawrence Berkeley Laboratory

W. U. SHIPLEY, Massachusetts General Hospital

E. L. TRAVIS, University of Texas

R. L. ULLRICH, University of Texas

R. R. WEICHSELBAUM, University of Chicago

\section{OFFICERS OF THE SOCIETY}

President: GEORGE M. HAHN, Department of Radiology, Stanford University School of Medicine, Stanford, California 94305

Vice President and President-Elect: JOEL S. BEDFORD, Department of Radiology and Radiation Biology, Colorado State University, Fort Collins, Colorado 80523

Secretary-Treasurer: E. JOHN AINSWORTH, Lawrence Berkeley Laboratory, University of California, Berkeley, California 94720

Editor-in-Chief: R. J. M. FRY, Biology Division, Oak Ridge National Laboratory, P.O. Box 2009, Oak Ridge, Tennessee 37831-8077

Administrative Director: MEG KEISER, 1101 Market Street-14th Floor, Philadelphia, Pennsylvania 19107

\section{ANNUAL MEETING}

1989: March 19-23, Seattle, Washington

Titus C. Evans, Editor-in-Chief Volumes 1-50

Oddvar F. Nygaard, Editor-in-Chief Volumes 51-79

Daniel Billen, Editor-in-Chief Volumes 80-113

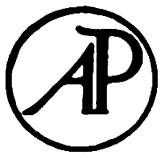


Councilors, Radiation Research Society 1988-1989

\section{PHYSICS}

G. C. Li, University of California, San Francisco

R. W. Wood, Department of Energy

\section{BIOLOGY}

R. E. Durand, British Columbia Cancer Reserch Centre, Vancouver, Canada

S. S. Wallace, University of Vermont

MEDICINE

E. L. Gillette, Colorado State University

R. C. Urtasun, University of Alberta, Canada

\section{CHEMISTRY}

J. A. Raleigh, University of North Carolina

J. L. Redpath, University of California, Irvine

AT-LARGE

H. H. Evans, Case Western Reserve University

J. E. Moulder, Medical College of Wisconsin 


\title{
CONTENTS OF VOLUME 116
}

\author{
NUMBER 1, OCTOBER 1988
}

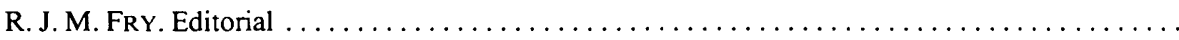

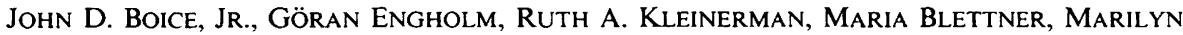
Stovall, Hermann lisco, William C. Moloney, Donald F. Austin, ANTONio Bosch, Diane L. CoOkfair, EdWARD T. Krementz, Howard B. LatouretTe, James A. MERrill, Lester J. Peters, Milford D. SChulz, Hans H. Storm, Elisabeth Björkholm, Folke Pettersson, C. M. Janine Bell, Michel P. Coleman, Patricia Fraser, Frank E. Neal, Patricia Prior, N. Won Choi, T. Gregory Hislop, Maria Koch, Nancy Kreiger, Dorothy Robb, Diane Robson, D. H. ThOMSON, H. LOCHMÜlleR, Dietrich Von Fournier, Rolf FrischKorn, KJell E. KJørstad, ARJa Rimpela, Marie-Hélène Pejovic, Vera Pompe Kirn, Hanna Stankusova, Franco Berrino, Kristjan Sigurdsson, George B. HutChison, AND BRIAN MaCMahon. Radiation Dose and Second Cancer Risk in Patients

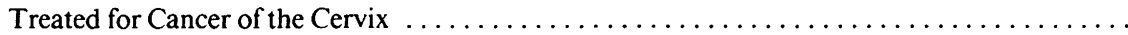

TaKashi Kondo, C. Murali Krishna, and Peter Riesz. Sonolysis, Radiolysis, and Hydrogen Peroxide Photolysis of Pyrimidine Derivatives in Aqueous Solutions: A Spin-Trapping Study

B. Fertil, P. J. Deschavanne, D. Debieu, and E. P. Malaise. Correlation between PLD Repair Capacity and the Survival Curve of Human Fibroblasts in Exponential Growth Phase: Analysis

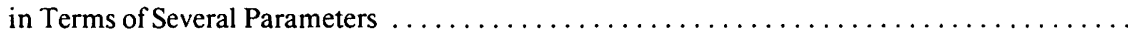

Liang-Yan Xue, LibBY R. Friedman, and NanCY L. OleinicK. Repair of Chromatin Damage in Glutathione-Depleted V-79 Cells: Comparison of Oxic and Hypoxic Conditions ..........

Sara Rockwell, Susan R. Keyes, and Alan C. Sartorelli. Preclinical Studies of Porfiromycin

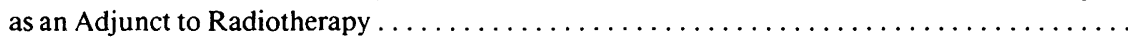

Harm H. Kampinga, William D. Wright, antonius W. T. Konings, and Joseph L. Roti RoTI. The Interaction of Heat and Radiation Affecting the Ability of Nuclear DNA to Undergo

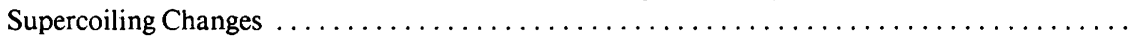

Vicram GuPTA AND James A. Belli. Enhancement of Radiation Sensitivity by Postirradiation Hypoxia: Time Course and Oxygen Concentration Dependency ..................

RaPHAEl GorodetSKy, WILliam H. MCBRIDE, AND H. RODNEY WitheRS. Assay of Radiation Effects in Mouse Skin as Expressed in Wound Healing $\ldots \ldots \ldots \ldots \ldots \ldots \ldots \ldots \ldots \ldots$

Renato G. Panizzon, Wayne R. Hanson, David E. Schwartz, and Frederick D. MalkinSON. Ionizing Radiation Induces Early, Sustained Increases in Collagen Biosynthesis: A 48Week Study in Mouse Skin and Skin Fibroblast Cultures .........................

Charles A. Vidair and William C. Dewey. Two Distinct Modes of Hyperthermic Cell Death . .

LETTERS TO THE EDITOR

D. J. BRENNER. Comments on "It Is Time to Reopen the Question of Thresholds in Radiation Exposure Responses" by J. R. Totter [Radiat. Res. 114, 1-2 (1988)] ............... WILliam H. ElletT. The BEIR IV Report $\ldots \ldots \ldots \ldots \ldots \ldots \ldots \ldots \ldots \ldots \ldots \ldots \ldots \ldots \ldots \ldots \ldots$ 172

BOOK REVIEWS

J. F. FowLER. Radiobiology for the Radiologist, 3rd ed., by Eric J. Hall . . . . . . . . . . . M. L. GRIEM. Innovations in Radiation Oncology, edited by H. Rodney Withers and Lester J. Peters

IN MEMORIAM

PETER HERRLICH. Karl Günther Zimmer (1911-1988) 
N. F. Metting, H. H. Rossi, L. A. Braby, P. J. Kliauga, J. Howard, M. Zaider, W. SchimmerLING, M. WONG, AND M. RAPKIN. Microdosimetry near the Trajectory of High-Energy Heavy Ions

Einar Sagstuen, Eli O. Hole, William H. Nelson, and David M. Close. ESR/ENDOR Study of Guanosine 5'-Monophosphate (Free Acid) Single Crystals X-Irradiated at $10 \mathrm{~K} \ldots \ldots \ldots$.

LiSa R. Karam, Miral Dizdaroglu, and Michael G. Simic. Intramolecular H Atom Abstraction from the Sugar Moiety by Thymine Radicals in Oligo- and Polydeoxynucleotides .......

Philip J. TOFILON AND RAYMOND E. MEYN. Influence of Cellular Differentiation on Repair of Ultraviolet-Induced DNA Damage in Murine Proadipocytes ...................

S. E. Sweigert, R. Rowley, R. L. Warters, and L. A. Dethlefsen. Cell Cycle Effect on the

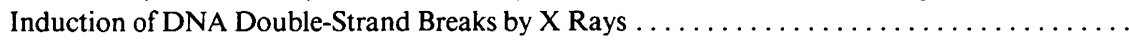

JAMES E. Cleaver. Proximity of Repair Patches to Persistent Pyrimidine Dimers in DNA of Normal

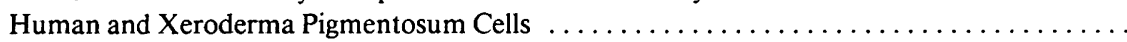

G. Guedeney, D. Grunwald, J. L. MALARbet, AND M. T. Doloy. Time Dependence of Chromosomal Aberrations Induced in Human and Monkey Lymphocytes by Acute and Fractionated

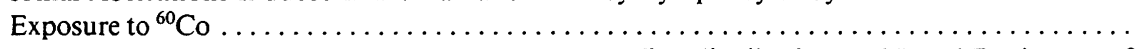

E. Polig, W. S. S. JeE, R. B. Dell, AND F. Johnson. Microdistribution and Local Dosimetry of

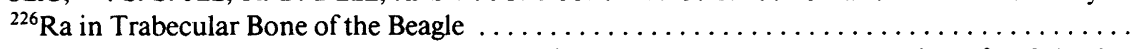

M. H. Schneiderman, K. G. Hofer, and G. S. Schneiderman. Cell Progression after Selective

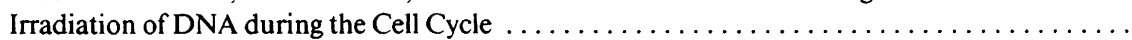

H. Roos, W.-H. Thomas, M. FitzeK, AND A. M. Kellerer. His ${ }^{+}$Reversions Caused in Salmonella typhimurium by Different Types of Ionizing Radiation $\ldots \ldots \ldots \ldots \ldots \ldots \ldots$

MARY PAT FELLENZ AND LEO E. GERWECK. Influence of Extracellular $\mathrm{pH}$ on Intracellular pH and Cell Energy Status: Relationship to Hyperthermic Sensitivity ...................

BARRY S. ROSENSTEIN. The Induction of DNA Strand Breaks in Normal Human Skin Fibroblasts

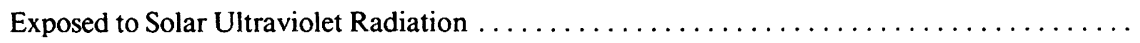

SANG Hie Kim, SEONG Su Hong, Alan A. Alfieri, AND JAE Ho KIM. Interaction of Hyperthermia

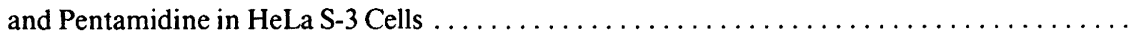

K. Kian Ang, Howard D. Thames, Sandra D. Jones, Guo-Liang Jiang, Luka Milas, and LESTER J. PETERS. Proliferation Kinetics of a Murine Fibrosarcoma during Fractionated Irradi-

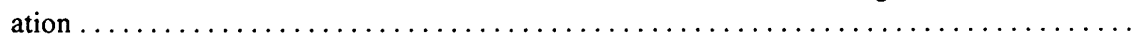

JAE Ho Kim, SANG HIE KIM, AND Alan A. ALFIERI. Selective Killing of Glucose-Deprived Hypoxic Cells by Hyperthermia. I. Protection by Purine Ribonucleosides $\ldots \ldots \ldots \ldots \ldots \ldots \ldots \ldots$

Eda T. Bloom, Mitoshi AKiyama, EdWard L. Korn, Yoichiro Kusunoki, and TaKashi MAKINODAN. Immunological Responses of Aging Japanese A-Bomb Survivors . . . . . . . . .

SHORT COMMUNiCATIONS

JAMES C. GARRISON AND EDWIN M. UYEKI. The Effects of $\gamma$ Radiation on Chondrogenic De-

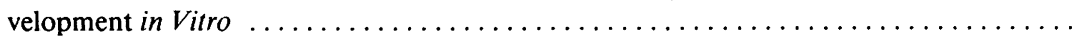
David B. Rubin, Elizabeth A. Drab, William F. Ward, and Kenneth D. Bauer. Cell Cycle Progression in Irradiated Endothelial Cells Cultured from Bovine Aorta . . . . . . . .

\section{NUMBER 3, DECEMBER 1988}

Howard Shields, Ysbrand Haven, Phillip J. Hamrick, JR., and Yi Ma. An ESR Study of the Radicals in X-Irradiated L- $\alpha$-Amino- $n$-butyric Acid $\mathrm{HCl}$ Containing $1.5 \%$ L-Cysteine $\mathrm{HCl}$

David M. Close, Einar Sagstuen, and William H. Nelson. Radical Formation in X-Irradiated Single Crystals of Guanine Hydrochloride Monohydrate. III. Secondary Radicals and Reaction

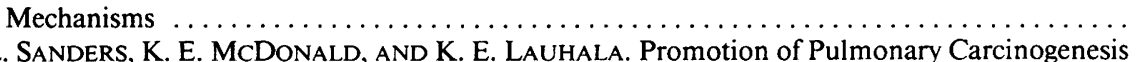

C. L. SANDERS, K. E. MCDONald, AND K. E. Lauhala. Promotion of Pulmonary Carcinogenesis
by Plutonium Particle Aggregation following Inhalation of ${ }^{239} \mathrm{PuO}_{2} \ldots \ldots \ldots \ldots \ldots \ldots \ldots \ldots$

P. Burgman AND A. W. T. Konings. Effect of Inhibitors of Poly(ADP-Ribose) Polymerase on the

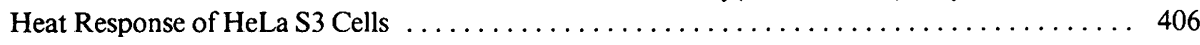


R. P. JENSH AND R. L. BRENT. The Effects of Prenatal X Irradiation on the Appearance of Reflexes

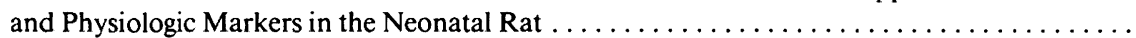

ANDREI LASZLO. Regulation of the Synthesis of Heat-Shock Proteins in Heat-Resistant Variants of

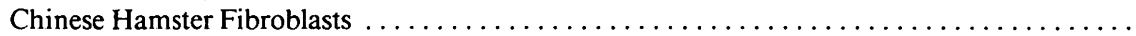

G. P. RAAPHORST AND E. I. AzZAM. Poly(ADP-ribose) Synthetase Inhibitors Increase Radiation and Thermal Sensitivity but Do Not Affect Thermotolerance .....................

J. RamSAY, H. D. Suit, F. I. PRefFer, AND R. SedlaCeK. Changes in Bromodeoxyuridine Labeling Index during Radiation Treatment of an Experimental Tumor . . . . . . . . . . . . . . . .

ROBERT E. KRISCH AND MARYANN B. Flick. Further Studies of the Induction and Intracellular Repair of DNA Strand Breaks Using Intranuclear SV40 as a Test System ............ 462

Mitsuru Neno and TATSUaKi KanaI. Interaction Function $\gamma(x)$ for Chinese Hamster Cells Treated with Hypertonic Phosphate-Buffered Saline after Irradiation $\ldots . \ldots \ldots \ldots \ldots \ldots$.

Herman D. Suit, Robert Sedlacek, Geoffrey Silver, Chung-Cheng Hsieh, Edward R. EPP, FRANK Q. H. NGO, William K. ROBERTS, AND LyNN Verhey. Therapeutic Gain Factors for Fractionated Radiation Treatment of Spontaneous Murine Tumors Using Fast Neutrons, Photons Plus $\mathrm{O}_{2} 1$ or 3 ATA, or Photons Plus Misonidazole $\ldots \ldots \ldots \ldots \ldots \ldots \ldots \ldots$

Vincenzo Covelli, Vincenzo Di Majo, Mario Coppola, Simonetta Rebessi, Caterina BanGRAZI, AND GINO DORIA. Late Somatic Effects in Mice after Total Lymphoid Irradiation ....

SuSANNA C. VANANKEREN, DAVID MURRAY, AND RAYMOND E. MEYN. Induction and Rejoining of $\gamma$-Ray-Induced DNA Single- and Double-Strand Breaks in Chinese Hamster AA8 Cells and

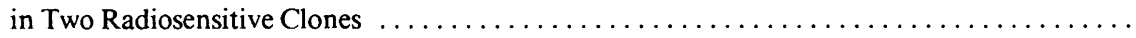

LLOYD R. KELLAND, STEPHEN M. EDWARDS, AND G. GORDON STEEL. Induction and Rejoining of DNA Double-Strand Breaks in Human Cervix Carcinoma Cell Lines of Differing Radiosensi-

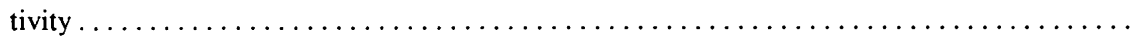

SHORT COMMUNICATION

Charles R. H. Kent AND Gerry H. BlekKenhorst. In Vivo Radiosensitization by Diethyldithiocarbamate

\section{LETTER TO THE EDITOR}

K. J. OlSEn AND J. W. HANSEN. On the Dose-Response Relationships following the Irradiation of Amino Acids

\section{ERRATUM}

Volume 114, Number 3, June 1988: Richard C. Miller, David J. Brenner, Charles R. Geard, Kenshi Komatsu, Stephen A. Marino, and Eric J. Hall, "Oncogenic Transformation by Fractionated Doses of Neutrons," pp.589-598 .......................

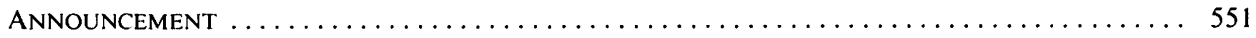

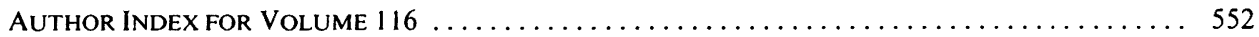

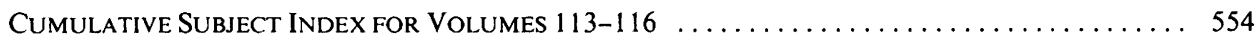




\title{
$\mathrm{His}^{+}$Reversions Caused in Salmonella typhimurium by Different Types of lonizing Radiation
}

\author{
H. Roos, W.-H. Thomas, M. FitzeK, AND A. M. Kellerer \\ Institut für Medizinische Strahlenkunde der Universität Würzburg, Versbacher Straße 5 , \\ D-8700 Würzburg, Federal Republic of Germany
}

Roos, H., Thomas, W.-H., Fitzek, M., AND Kellerer, A. M. $\mathrm{His}^{+}$Reversions Caused in Salmonella typhimurium by Different Types of Ionizing Radiation. Radiat. Res. 116, 292304 (1988).

\begin{abstract}
The yield of his $^{+}$reversions in the Ames Salmonella tester strain TA2638 has been determined for ${ }^{60} \mathrm{Co} \gamma$ rays, $140 \mathrm{kV} \mathrm{X}$ rays, $5.4 \mathrm{keV}$ characteristic $\mathrm{X}$ rays, $2.2 \mathrm{MeV}$ protons, $3.1 \mathrm{MeV} \alpha$ particles, and $18 \mathrm{MeV} / \mathrm{U}$ Fe ions. Inactivation studies were performed with the same radiations. For both mutation and inactivation, the maximum effectiveness per unit absorbed dose was obtained for the characteristic $\mathrm{X}$ rays, which have a dose averaged linear energy transfer (LET) of roughly $10 \mathrm{keV} / \mu \mathrm{m}$. The ratio of the effectiveness of this radiation to $\gamma$ rays was 2 for inactivation and about 1.4 for the his $^{+}$reversion. For both end points the effectiveness decreases substantially at high LET, i.e., for the $\alpha$ particles and the Fe ions. The composition of the bottom and the top agar was the one recommended by Maron and Ames [Mutat. Res. 113, 173-215 (1983)] for application in chemical mutagenicity tests. The experiments with the less penetrating radiations differed from the usual protocol by utilization of a technique of plating the bacteria on the surface of the top agar. As in an earlier study [Roos et al., Radiat. Res. 104, 102-108 (1985)] greatly enhanced yields of mutations, relative to the spontaneous reversion rate, were obtained in these experiments by performing the irradiations $6 \mathrm{~h}$ after plating, which differs from the conventional procedure to irradiate the bacteria shortly after plating. (๑) 1988 Academic Press, Inc.
\end{abstract}

\section{INTRODUCTION}

The Salmonella mutagenicity test ( 1 ) is the most widely used short term test for chemical mutagens, and it is therefore desirable to examine its response to different types of ionizing radiation. Several investigations have been performed in the past. Of special importance are the studies of Isildar and Bakale, who have made a broad investigation of the effects of sparsely ionizing radiations on six of the most common tester strains $(2,3)$, and the work of Imray and McPhee, which includes an assessment of the influence of plasmids (4). In the earlier investigations the test appeared to be relatively insensitive to ionizing radiation. However, this apparent lack of sensitivity resulted because brief exposures were applied shortly after plating. While this was in seeming analogy to the work with chemical mutagens, it did not account for the difference between the short duration of the irradiation and the continued presence of chemical mutagens. The mutation frequencies were greatly enhanced relative to the spontaneous rates when a modified procedure was introduced (5) where the exposures were performed at a later phase during incubation ( $6 \mathrm{~h}$ after plating). With this new method a doubling dose of only $1.3 \mathrm{~Gy}$ of ${ }^{60} \mathrm{Co} \gamma$ rays was found for the strain 


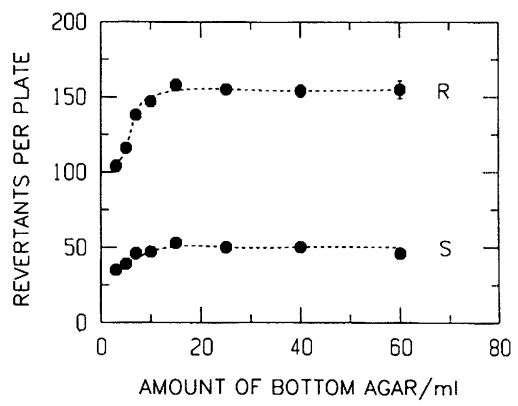

FIG. 1. Number of spontaneous revertants (S) and number of revertants (R) after exposure to 9.5 Gy of ${ }^{60} \mathrm{Co} \gamma$ ray's versus the amount of bottom agar. Exposures were performed immediately after plating. A plateau at about three times higher frequency of the induced reversions was obtained for exposure with preincubation.

TA2638, and other strains showed similarly reduced doubling doses. Inactivation corrections, which were essential with the conventional method, are of less influence with the new technique.

The aim of the present study, with the improved experimental procedure, was the determination of the relative effectiveness of various ionizing radiations. There is still insufficient understanding of the different results obtained for radiation-induced mutagens in mammalian cells and in prokaryotes. In mammalian cells one finds, both for inactivation and for mutational tests such as the hypoxanthine-guanine phosphoribosyl transferase test, increased efficiencies for densely ionizing radiations with a maximum near linear energy transfer (LET) of $100 \mathrm{keV} / \mu \mathrm{m} \mathrm{(6).} \mathrm{In} \mathrm{their} \mathrm{work}$ with $E$. coli Munson and co-workers $(7,8)$ have found increased efficiencies of inactivation for radiations of intermediate LET. They infer from their experiments a peak at an LET of about $20 \mathrm{keV} / \mu \mathrm{m}$, and they find a steep decrease in efficiency at higher LET. A corresponding peak was not seen in mutagenicity studies performed by these authors; they found that mutations to prototrophy of three auxotrophic strains of $E$. coli are induced with an effectiveness which decreases steadily with increasing LET. In view of these findings it seemed desirable to perform analogous studies for the Salmonella mutagenicity test with radiations that cover a broad range of LET. We have chosen ${ }^{60} \mathrm{Co} \gamma$ rays, $140 \mathrm{kV} \mathrm{X}$ rays $(9-\mathrm{mm}$ aluminum filter), $5.4 \mathrm{keV} \mathrm{Cr}-\mathrm{K} \alpha$ characteristic $\mathrm{X}$ rays, protons of $2.2 \mathrm{MeV}, \alpha$ particles of $3.1 \mathrm{MeV}$, and, for very high LET, Fe ions of $18 \mathrm{MeV} / \mathrm{U}$.

\section{MATERIALS AND METHODS}

\section{Bacterial Strain}

The tester strain TA2638 (hisG428, rfa, pKM101) was provided by Dr. B. N. Ames, Department of Biochemistry, University of California, Berkeley.

Among a variety of tester strains, we have found particularly high mutation yields with ionizing radiations not only in TA2638 but also in TA 102. The former was selected for the present studies because of its special stability and its low spontaneous reversion rate. We have also found it advantageous to use a strain which, unlike TA 102, contains no plasmid carrying the his $^{-}$site; the number of plasmids per cell is difficult to control and can be a potential source of instability in the experimental results. The genetic stability of the strain TA2638 was routinely tested for crystal-violet sensitivity (rfa mutation), uv sensitivity (uvrB 


\section{TABLE I}

Half-Value Layers of the Photon Radiations and Ranges of the Charged Particles in Agar; Dose Averaged Restricted LET (100 eV Cutoff) and Dose Averaged Unrestricted LET

\begin{tabular}{|c|c|c|c|c|c|}
\hline photons & half-volue layer & \multicolumn{2}{|c|}{$\bar{L}, 00,0$} & \multicolumn{2}{|c|}{$\bar{L}_{\infty, D}$} \\
\hline$Y$ rays $\left({ }^{60} \mathrm{Co}\right)$ & $1080 \mathrm{~mm}$ & 5.53 & $1 / \mu \mathrm{m}$ & 0.40 & $1 / \mu m$ \\
\hline$X$ rays $(140 \mathrm{kV})$ & $380 \quad " 1$ & 8.31 & $" 1$ & 4.29 & $\because 1$ \\
\hline$X$ roys $(5.4 \mathrm{keV})$ & $0.23 \quad 11$ & 11.3 & " & 9.66 & 11 \\
\hline charged porticles & ronge & & & & \\
\hline$(18 \mathrm{MeV} / \mathrm{u})$ & $0.480 \quad 11$ & 469 & $"$ & 1690 & $" 1$ \\
\hline$(2.2 \mathrm{MeV})$ & $0.090 \quad 1$ & 12.3 & " & 15.2 & " \\
\hline a particles $(3.1 \mathrm{MeV})$ & $0.017 \quad$ י & 47.9 & $\because$ & 132 & 11 \\
\hline
\end{tabular}

mutation), and ampicillin resistance (pKM 101). In a series of investigations in our laboratory, extended over about 4 years, strain TA2638 has exhibited remarkable stability in the frequency of spontaneous and radiation-induced revertants and also in inactivation yields after exposure to ionizing radiation.

\section{Preparation of Samples}

The recommendations of Maron and Ames (9) have been followed with the minor modification of using a bottom-agar layer consisting of $25 \mathrm{ml}$ glucose-agar medium instead of $30 \mathrm{ml}$. That this modification is of negligible influence in our experiments with ionizing radiation can be judged from the data in Fig. 1 .

All chemicals were of analytical grade; water was deionized and quartz distilled. Oxoid and Difco media were used. Cultures of bacteria were started with $0.4 \mathrm{ml}$ bacterial suspension from frozen permanent stocks, and plating was performed toward the end of the exponential phase $(8 \mathrm{~h})$. Further details have been given in the preceding publication (5).

Among the six different radiations which were employed (see Table I), two were sufficiently penetrating to permit the normal method of sample preparation in which $0.1 \mathrm{ml}$ bacterial suspension (containing about $5 \cdot 10^{8}$ bacteria) is mixed with $2 \mathrm{ml}$ top agar and poured onto minimal glucose agar plates (diameter 85 $\mathrm{mm}$ ). This results in a $0.3-\mathrm{mm}$ top-agar layer which contains the bacteria. The number of plated bacteria is fairly uncritical in the reversion experiments with our modified technique, because the number of revertants per plate is, over a certain range, nearly independent of this parameter (5).

For the less penetrating radiations ( $5.4 \mathrm{keV}$ characteristic $\mathrm{X}$ rays, $2.2 \mathrm{MeV}$ protons, $3.2 \mathrm{MeV} \alpha$ particles, and $18 \mathrm{MeV} / \mathrm{U} \mathrm{Fe}$ ions) the technique of sample preparation had to be modified. This critical aspect of the experiments must be considered in some detail.

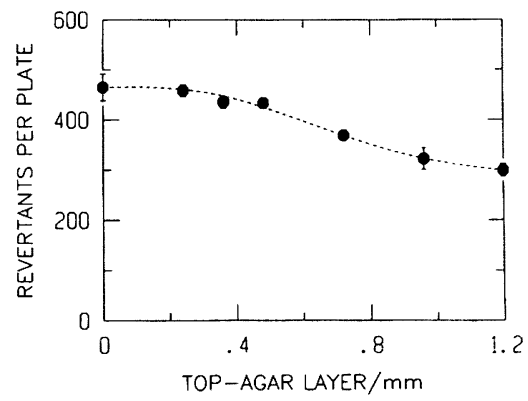

FIG. 2. Number of radiation-induced revertants per plate (revertants minus spontaneous revertants) versus thickness of the top-agar layer. The samples were exposed to $9.5 \mathrm{~Gy} \mathrm{of}{ }^{60} \mathrm{Co} \gamma$ radiation. 
TABLE II

Comparison of the Surface Plating Technique and the Standard Technique

\begin{tabular}{|l|c|c|}
\hline observation & $\begin{array}{c}\text { number of } \\
\text { experiments }\end{array}$ & $\begin{array}{c}\text { surfoce-plating techn. } \\
\text { standard technique }\end{array}$ \\
\hline plating eff. & 10 & $1.01 \pm 0.01$ \\
\hline revertants & 11 & $1.03 \pm 0.01$ \\
\hline spont.rev. & 7 & $1.10 \pm 0.02$ \\
\hline inoctivation & 20 & $1.03 \pm 0.04$ \\
\hline
\end{tabular}

Note. The irradiations were performed by ${ }^{60} \mathrm{Co} \gamma$ rays. In the mutation experiments the absorbed dose was $8 \mathrm{~Gy}$; different doses between 7 and $50 \mathrm{~Gy}$ were applied in the inactivation experiments. The errors given are standard errors.

Reduction of the amount of top agar would be one possibility to concentrate the bacteria on the surface (see Fig. 2). For zero top-agar thickness the standard supplements of $0.1 \mu M$ D-biotin and $0.1 \mu M$ L-histidine were mixed with the bacterial suspension, and the resulting volume of $0.3 \mathrm{ml}$ was then spread directly on the bottom-agar surface. The suspension liquid enters the bottom agar, but the bacteria remain on its surface so that the radiation needs to penetrate only the bacteria (long and short diameter about 2 and $1 \mu \mathrm{m})$.

In an alternative method, the $0.1 \mathrm{ml}$ of bacterial suspension was spread on the surface of the solidified top agar (containing the supplement of biotin and histidine) with a Drigalski spatule. This method has been chosen for the experiments because it departs less from the standard procedure. The standard method, where the bacteria are distributed within the top-agar layer, and the surface-plating technique, where they are spread on the surface of the top agar, were compared for plating efficiency, number of spontaneous revertants, number of radiation-induced revertants, and inactivation of the bacteria by ionizing radiation (see Table II). A certain difference was seen for the frequencies of spontaneous revertants which were increased from 50 to about 55 per plate. This difference, however, is not directly relevant to the subsequent comparison of the effectiveness of different radiations which is evaluated in terms of the slope of the dose dependence.

\section{Methods of Irradiation and Dosimetry}

All exposures were performed at room temperature. The dose rate of photons and $\alpha$ particles was adjusted to $0.2 \mathrm{~Gy} / \mathrm{min}$ in the mutation experiments. For technical reasons, the dose rate at the accelerators had to be higher; it was adjusted to $10 \mathrm{~Gy} / \mathrm{min}$ for both the proton and the $\mathrm{Fe}$ ion exposures.

In the photon and $\alpha$ particle exposures the samples were kept out of the incubator for the same time (approximately $1 \mathrm{~h}$ ) regardless of dose. All exposures less than $10 \mathrm{~Gy}$ were split into two fractions with an interval chosen so that the total duration and therefore the time outside the incubator was always 50 min. The split-dose irradiations were compared with equal single doses applied either at the beginning or at the end of the $50 \mathrm{~min}$ period. There were no systematic differences, and one can therefore conclude that variation of the total exposure time from 10 to $50 \mathrm{~min}$ is of little importance.

With regard to the accelerator experiments one must still ask whether there is a time factor at the substantially higher dose rates and the short exposure times of one or a few minutes. Additional experiments were therefore performed (at the GSF, Munich) with a dose rate of $2 \mathrm{~Gy} / \mathrm{min}{ }^{60} \mathrm{Co} \gamma$ radiation; the results are consistent with those obtained at $0.2 \mathrm{~Gy} / \mathrm{min}$ (see Fig. 3). One concludes that differences observed between photon and charged particle irradiations are not a matter of different dose rates.

In the inactivation experiments substantially higher doses were required, and this necessitated a substantially prolonged exposure time of $2 \mathrm{~h}$ for the highest dose, $25 \mathrm{~Gy}$ of $\alpha$ rays. For the Co $\gamma$ exposures and the soft $\mathrm{X}$-ray exposures it was possible to keep the exposure times at $1 \mathrm{~h}$ by varying the exposure distances. 


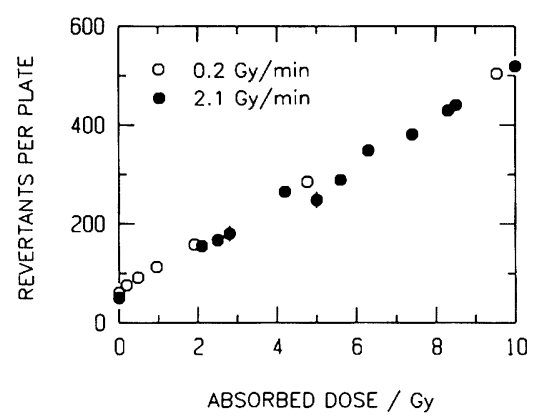

FIG. 3. Revertants per plate versus absorbed dose. The irradiations were performed with ${ }^{60} \mathrm{Co} \gamma$ rays, and different dose rates were compared.

Additional experiments (at the GSF, Munich) with Co $\gamma$ rays at $25 \mathrm{~Gy} / \mathrm{min}$ again did not indicate the presence of a time factor (Fig. 4). For the inactivation experiments, too, one must therefore conclude that the comparison to the accelerator experiments $(10 \mathrm{~Gy} / \mathrm{min})$ is unaffected by differences in dose rate.

The $\gamma$ exposures were performed with a ${ }^{60} \mathrm{Co}$ therapy unit. Exceptions were the additional high-dose rate experiments which utilized two calibrated ${ }^{60} \mathrm{Co}$ sources at the GSF, Munich.

The $140 \mathrm{kV} \mathrm{X}$ rays were produced by a $150 \mathrm{kV}$ tube with beryllium window (Philips, MÖD $152 \mathrm{BE}$ ) operated at $140 \mathrm{kV}$ and were filtered by $9 \mathrm{~mm}$ aluminum. Characteristic $\mathrm{X}$ rays were generated by a tube with $\mathrm{Cr}$ anode and beryllium window (Siemens, AG CR 61). The tube was operated at $10 \mathrm{kV}$ to produce $5.4 \mathrm{keV} \mathrm{Cr}-K \alpha$ characteristic $\mathrm{X}$ rays. The radiation was filtered by a $20-\mu \mathrm{m} \mathrm{Cr}$ foil to reduce the bremsstrahlung (see (10)).

Photon dosimetry was performed with a calibrated therapy-dosimetry system (Dosimentor system; Dr. Pychlau GmbH, Freiburg) with suitable ionization chambers. An ionization chamber of type M 23342 was used for the dosimetry of soft $\mathrm{X}$ rays. A calibration factor for this chamber is usually provided for low energy photons of $8.4 \mathrm{keV}$. The calibration factor for photons of $5.4 \mathrm{keV}$ is $2 \%$ in excess of the value for $8.4 \mathrm{keV}$; it was kindly provided by Dr. P. Pychlau, GmbH, Freiburg (personal communication). The chambers are calibrated for measuring exposure; conversion to absorbed dose utilized the appropriate massenergy absorption coefficients for tissue $\left({ }^{60} \mathrm{Co} \gamma\right.$ rays: $37.2 \mathrm{~Gy} /(\mathrm{C} / \mathrm{kg}) ; 140 \mathrm{kV}$ X rays: $34.9 \mathrm{~Gy} /(\mathrm{C} / \mathrm{kg}) ; 5.4$ $\mathrm{keV}$ characteristic $\mathrm{X}$ rays: $35.7 \mathrm{~Gy} /(\mathrm{C} / \mathrm{kg})) .3 \mathrm{MeV}$ protons were delivered by the $3 \mathrm{MV}$ van de Graaff generator of the GSF. A device to achieve homogenous irradiations of $85 \mathrm{~mm}$ petri dishes was constructed for this experiment (Fig. 5). The proton beam left the accelerator through a 4- $\mu \mathrm{m}$ titanium exit foil. This foil was supported by a beam defining slit $(22 \mathrm{~mm} \times 0.5 \mathrm{~mm})$. The sample was exposed to the beam on a

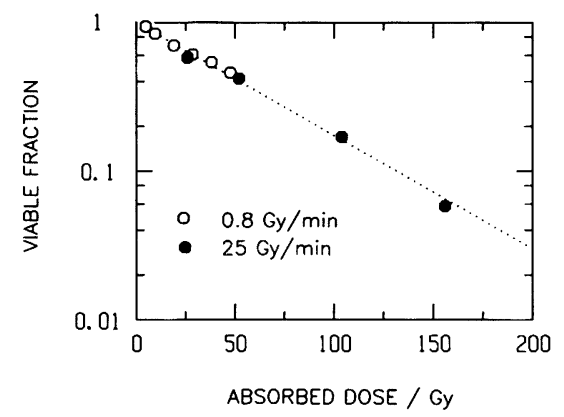

FIG. 4. Viable fraction of bacteria versus absorbed dose. The irradiations were performed with ${ }^{60} \mathrm{Co} \gamma$ rays, and different dose rates were compared. 


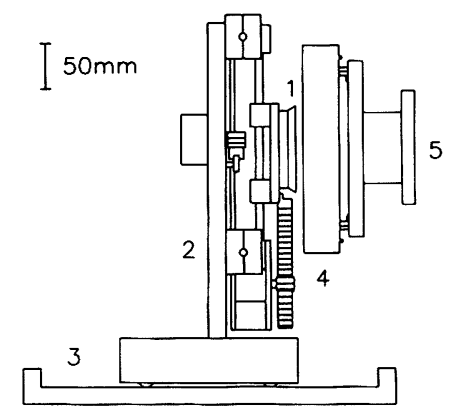

Fig. 5. Diagram of the device for proton irradiations. 1, sample; 2 , scanning device (retractabie from the ionization chamber for changing the sample by means of the guide way, 3 ); 4 , ionization chamber; 5 , adaptor to beam-guide tube with exit window (not visible).

computer controlled device for two-dimensional scanning. For the smallest doses a single scan was performed, for the higher doses several scans. The proton-beam current was monitored with a thin-window transmission ionization chamber located between exit window and sample. This monitor was calibrated by comparison with the proton fluence determined from etched particle tracks in $\mathrm{Cr} 39$ plastics. Traversal of the Ti-exit window and of the monitor ionization chamber reduced the proton energy from $3 \mathrm{MeV}$ to $2.2 \mathrm{MeV}$ (for details see $(I /)$ ). Absorbed dose was calculated from the measured particle fluence with the LET value $15.0 \mathrm{keV} / \mu \mathrm{m}$ recommended by ICRU report 36 (12).

The construction of the $\alpha$ irradiator is indicated in Fig. 6 (for details see (13)). Alpha particles emerging from the ${ }^{241} \mathrm{Am}$ source (activity $0.37 \mathrm{GBq}$, energy of $\alpha$ particles $5.53 \mathrm{MeV}$, diameter of active area $85 \mathrm{~mm}$ ) are collimated to an angle less than $12^{\circ}$ from the normal. The collimator removes $\alpha$ particles which leave the source obliquely; this avoids a sharp decrease of absorbed dose with depth in the irradiated sample. To reduce energy loss, source and collimator are mounted in a container which is flushed with helium under normal pressure. In comparison to air, this reduces energy losses by a factor of more than 6 . The exit foil can be thin ( $2.5 \mu \mathrm{m}$ Mylar) since it supports no pressure differences. Petri dishes are exposed to the $\alpha$ rays in inverted position; the distance between exit window and top agar is $1 \mathrm{~mm}$. The collimator is wobbled in circular motion; this reduces the maximal difference of the fluence on the exit window from $4 \%$ for a fixed position of the collimator to less than $1 \%$. Both values apply for a homogenous source. To improve homogeneity the source is rotated. Measured over a spot of $6 \mathrm{~mm}^{2}$ area there are maximum differences of intensity on the surface of the source of about $20 \%$. With rotating source the corresponding maximum differences on the surface are less than 3\%. The energy distribution of $\alpha$-particle fluence after traversal of the exit window (see Fig. 7) was measured with a semiconductor detector. The most probable $\alpha$-particle

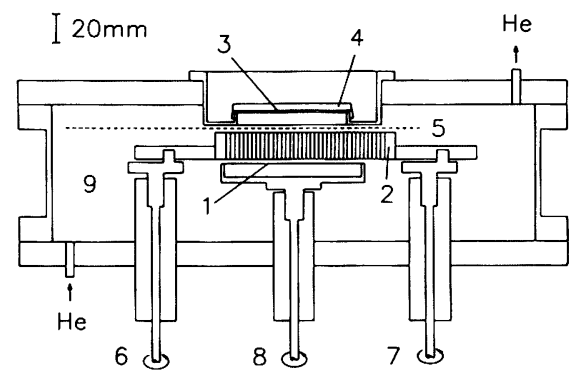

FlG. 6. Simplified view of the $\alpha$-irradiation device. 1, source; 2, moving collimator; 3, exit window; 4, sample; 5 , shutter; 6,7 , synchronously rotating axes supporting the collimator; 8 , rotating axis supporting the source-turn table; 9 , helium container. 


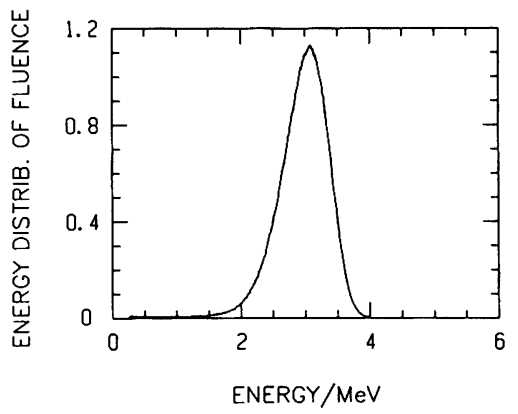

FIG. 7. Measured energy distribution of $\alpha$-particle fluence after traversal of the exit window.

energy is $3.1 \mathrm{MeV}$. From the data of Fig. 7 the sum distribution of remaining ranges (Fig. 8) and the depth distribution of dose in tissue (Fig. 9) was calculated with LET data from ICRU report 36.

Irradiations with $18 \mathrm{MeV} / \mathrm{U}$ Fe ions were performed at the linear accelerator UNILAC of the GSI (Darmstadt). The samples were irradiated in an exposure facility with an automatic sample changer constructed by the GSI (14). The beam was defocused and the samples were wobbled to achieve homogenous irradiations. An integrated part of the exposure facility is a secondary electron emission chamber monitoring the Fe-ion beam current. This monitor was calibrated by comparison with the particle fluence determined from track counts on etched glass samples. Absorbed dose was calculated from the measured particle fluence with LET data of Ziegler (15).

\section{RESULTS}

The experimental results on bacterial survival and on the frequency of revertants per plate are represented in Figs. 10 and 11. In the inactivation studies the individual points are mean values for at least six plates; some points have been derived from larger numbers of plates. In most experiments data points have been obtained from repeated experiments. In the work with Fe ions at the GSI such repetitions were not possible, and all points are the result of one experiment obtained with the same bacterial culture. The data for the protons are based on two separate experiments which indicated no systematic deviations. Standard errors were derived from counts on the plates exposed to the same dose in an experiment; where they are not visible in the

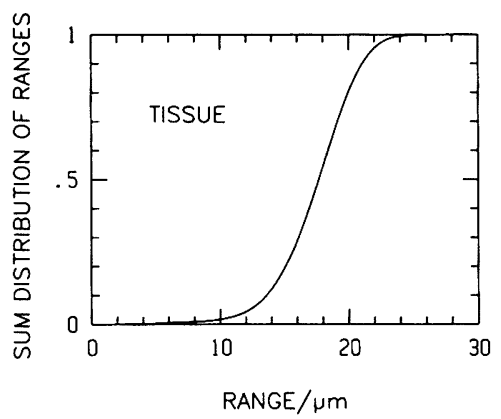

FIG. 8. Sum distribution of remaining ranges in tissue for direct exposition of the samples at the exit window. 


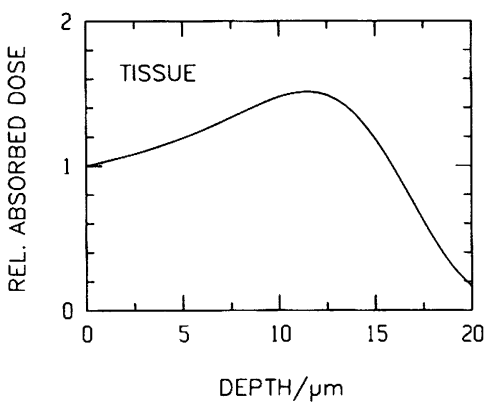

FIG. 9. Relative absorbed dose versus depth in tissue.

diagrams they are smaller than the symbols. The standard errors do not account for errors between different dose points, due for example to inaccuracies in the dilution series, nor do they account for fluctuations between experiments. The overall influ-
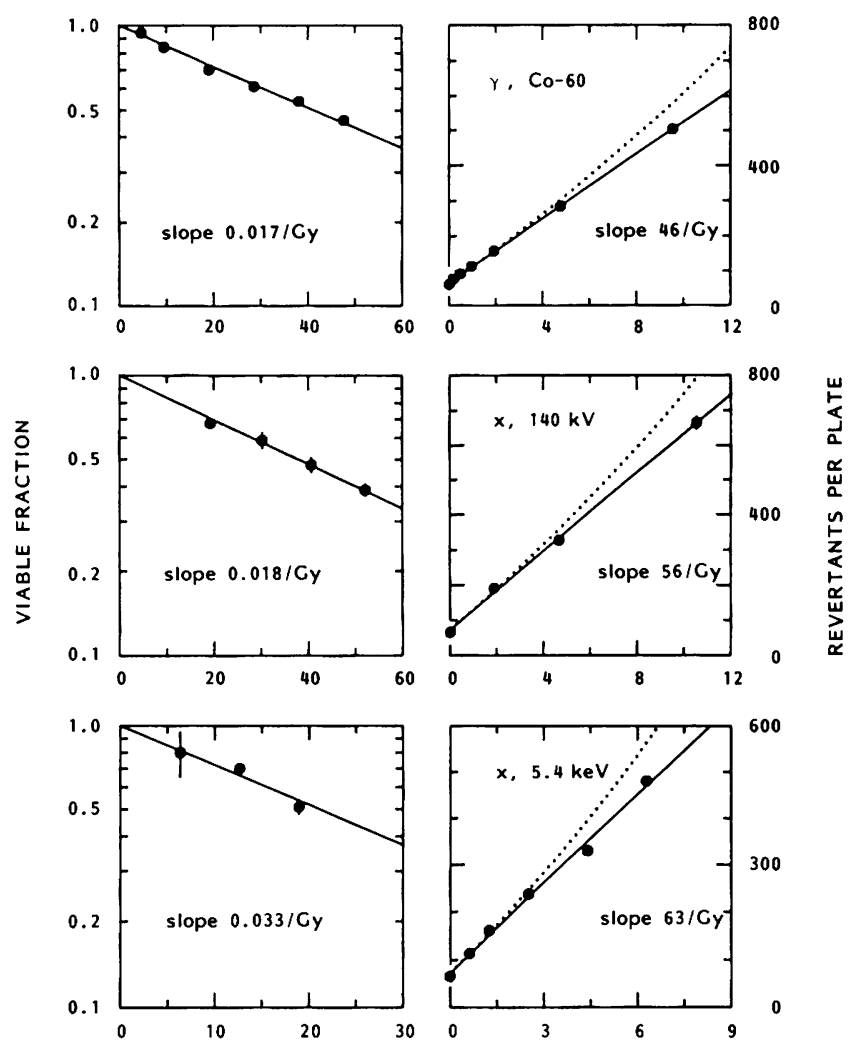

ABSORBED DOSE / CY

FIG. 10. Viable fraction of irradiated bacteria (left panels) and number of revertants per plate (right panels) versus absorbed dose. Samples exposed to ${ }^{60} \mathrm{Co} \gamma$ rays, $140 \mathrm{kV}$ X rays filtered by $9 \mathrm{~mm} \mathrm{Al}$, and 5.4 $\mathrm{keV} \mathrm{Cr}-\mathrm{K} \alpha$ characteristic $\mathrm{X}$ rays. Dotted lines represent the data with inactivation correction. 

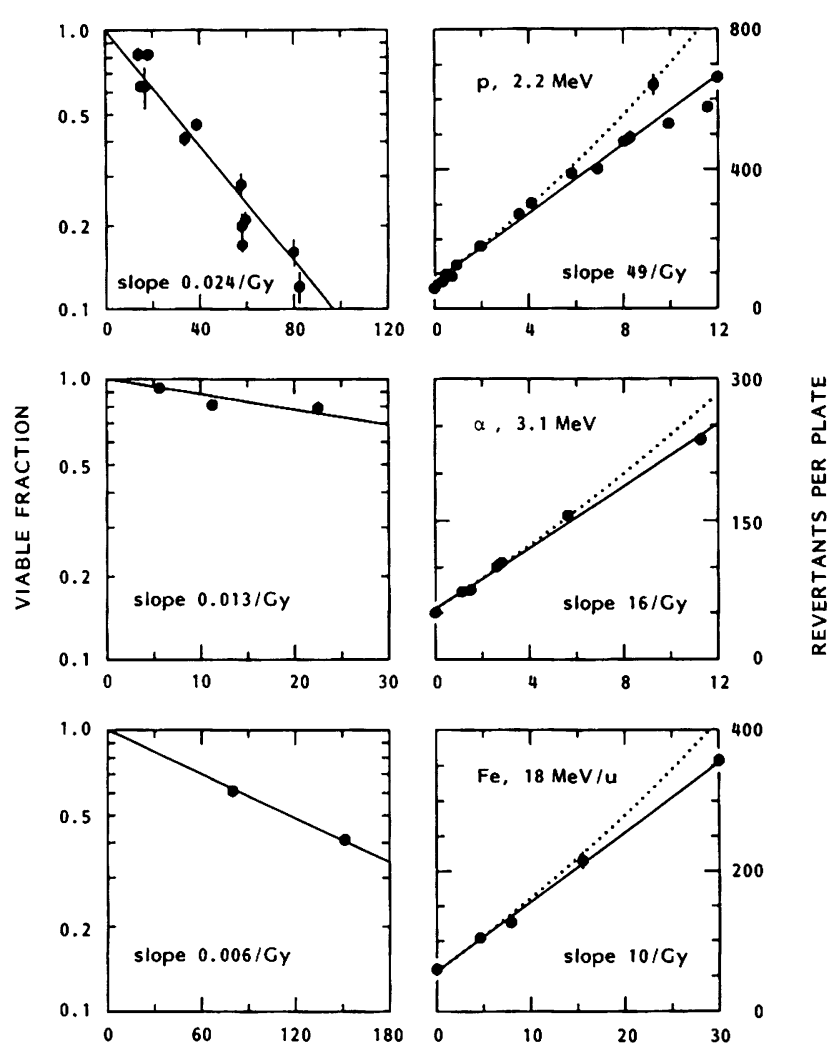

ABSORBED DOSE / Gy

FIG. 11. Viable fraction of irradiated bacteria (left panels) and number of revertants per plate (right panels) versus absorbed dose. Samples exposed to $2.2 \mathrm{MeV}$ protons, $3.1 \mathrm{MeV} \alpha$ particles, and Fe ions of $18 \mathrm{MeV}$ per nucleon. Dotted lines represent the data with inactivation correction.

ence of such errors can be judged from the spread of the points in individual doseeffect relations. The solid lines are least-squares fits to the observations, with equal weights for all points.

All survival curves are consistent with exponential relations. Even for the $\gamma$ rays and the higher energy $X$ rays there is no indication of a shoulder. With decreasing photon energy slopes are increasing. Because of the marked differences of effectiveness, different dose scales had to be used. Figure 12 serves to facilitate the comparison. The highest effectiveness for inactivation is found with $5.4 \mathrm{keV} \mathrm{X}$ rays (slope: 0.033 / Gy), the lowest effectiveness with $18 \mathrm{MeV} / \mathrm{U}$ Fe ions (slope: $0.006 / \mathrm{Gy}$ ). The numbers of revertants per plate were consistent with linear dependences on absorbed dose. Inactivation corrections were of minor influence (see dotted lines in Figs. 10 and 11), since the largest inactivated fraction corresponding to any of the points in the mutation studies was only 0.25 . The mutagenicity, too, increases with decreasing photon energy; the comparison is facilitated by Fig. 13. As in the inactivation experiments, 


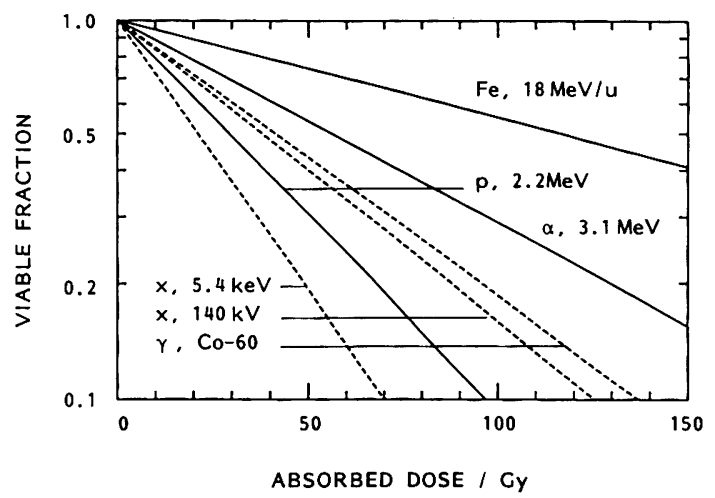

FIG. 12. Exponential functions of dose fitted to the observed viable fractions of irradiated bacteria for the six different radiations (see Figs. 10 and 11 ).

the soft $\mathrm{X}$ rays were most effective (doubling dose: $2.3 \mathrm{~Gy}$ ), whereas the Fe ions were far less effective (doubling dose: $11.4 \mathrm{~Gy}$ ).

\section{DISCUSSION}

The delayed exposure method was used for the Salmonella mutagenicity test to perform experiments with tester strain TA2638 (hisG428, rfa, pKM101) exposed to six different types of ionizing radiation. The modified method results in substantially enhanced yields of mutations, reducing the relative contribution of the spontaneous revertants and making inactivation corrections less necessary. The radiations which were employed covered a wide range of LET from sparsely ionizing $\gamma$ rays to heavy ions of $1700 \mathrm{keV} / \mu \mathrm{m}$. The results show a pronounced peak of inactivation for the $5.4 \mathrm{keV}$ characteristic $\mathrm{X}$ rays. These have a dose average LET of approximately 10

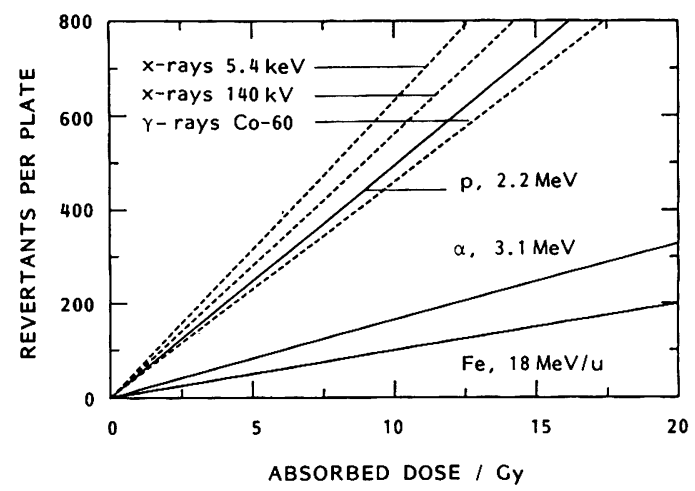

FIG. 13. Linear regressions in dose of the observed numbers of revertants per plate for the six different radiations (see Figs. 10 and 11). 

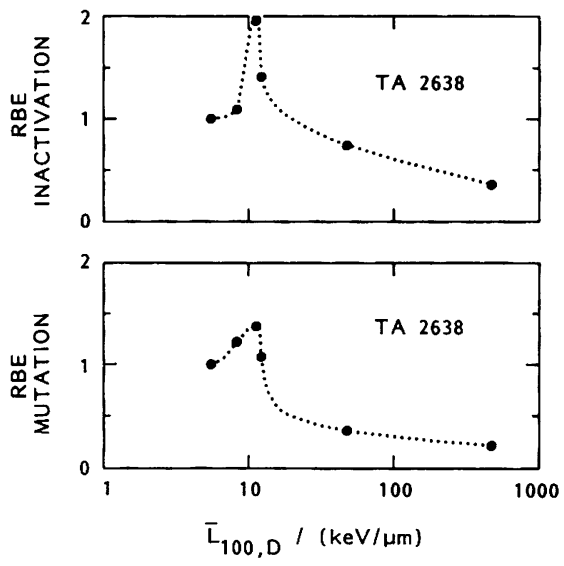

FIG. 14. RBE for inactivation (upper panel) and mutation (lower panel) of the bacteria by the different radiations. The dose average restricted LET ( $100 \mathrm{eV}$ cutoff) is chosen as reference parameter (from left: ${ }^{60} \mathrm{Co} \gamma$ rays, $140 \mathrm{kV} \mathrm{X}$ rays, $5.4 \mathrm{keV} \mathrm{X}$ rays, protons, $\alpha$ particles, Fe ions). The dotted lines are inserted for better readability of the diagrams; they have no mathematical significance.

$\mathrm{keV} / \mu \mathrm{m}$, largely independent of the cutoff that is employed. A similar but less pronounced peak is seen for the mutations.

The occurrence of a peak for inactivation at moderate values of LET is in substantial agreement with the earlier findings of Munson and colleagues $(7,8)$ for inactivation of $E$. coli by different types of ionizing radiation. These authors have not reported a similar peak for mutations to prototrophy in $E$. coli $\mathrm{B} / \mathrm{r}$. However, their results and the related data of Munson and Bridges (16) on bacterial phage T4 need not necessar-
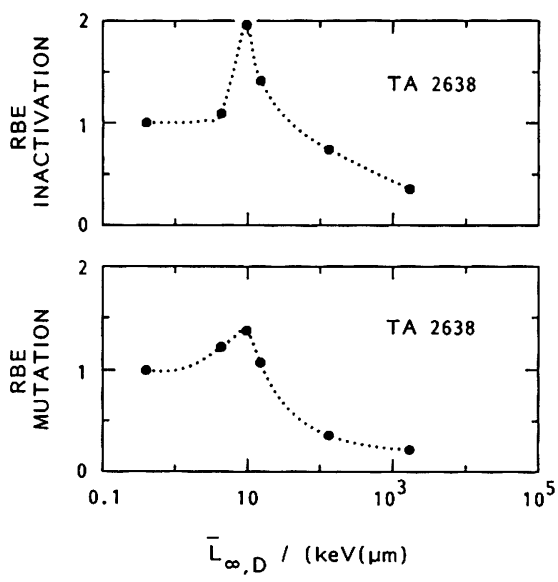

FIG. 15. RBE for inactivation (upper panel) and mutation (lower panel) of the bacteria by the different radiations. The dose average unrestricted LET is chosen as reference parameter (from left: ${ }^{60} \mathrm{Co} \gamma$ rays, 140 $\mathrm{kV} \mathrm{X}$ rays, $5.4 \mathrm{keV} \mathrm{X}$ rays, protons, $\alpha$ particles, Fe ions). The dotted lines are inserted for better readability of the diagrams; they have no mathematical significance. 
ily be inconsistent with a peak of RBE for mutations near LET $=10 \mathrm{keV} / \mu \mathrm{m}$, as we see it in the present experiments. From our study one would infer that RBE values for inactivation and mutation in bacteria are largely parallel.

Various authors have developed models to link energy concentrations in cellular and subcellular structures to the effectiveness of different types of ionizing radiations in causing mutations and cell inactivation (see e.g. (17)). Such models utilize either the concept of LET or microdosimetric quantities. The microdosimetric quantities depend on the assumed target structure and size, and it would be highly tentative to relate the present observations to specific parameters. The LET concept, on the other hand, is a simplification but it has the advantage of being less closely linked to assumptions on the structure of the relevant targets. It is therefore of some interest to correlate the observed data with restricted and unrestricted LET and its mean values. Such a correlation, although largely empirical, can bring out essential features of the results.

On the basis of present radiobiological understanding it has been variously suggested that the effectiveness of different types of ionizing radiation is linked to DNA damage produced by energy concentrations on the nanometer scale. Short of a microdosimetric treatment, such energy concentrations need to be linked to restricted LET rather than total LET which includes the long-range $\delta$ rays. Blohm and Harder (18) have held that the dose mean LET with a cutoff of $100 \mathrm{eV}$ is the appropriate quantity. In the two panels of Fig. 14 the RBE for inactivation and mutation is plotted versus the dose average of restricted LET $(\Delta=100 \mathrm{eV})$. The averages of LET for the different radiations are based on work of Harder and Blohm (19); they are derived by averaging the contributions of the heavy particles and those of the $\delta$ rays that exceed the cutoff energy. The inclusion of the $\delta$ rays is essential for the protons; without this contribution they would be assigned LET values which are substantially too low. The sharp peaks in Fig. 14 are striking and may suggest that $\bar{L}_{100, D}$ is not the suitable parameter. The soft $X$ rays have very nearly the same mean values of restricted LET as the protons, but their effectiveness with regard to both mutation and inactivation is substantially larger. This may imply that the effect is determined not only by energy concentrations over distances of one or a few nanometers but also by energy concentrations over a larger scale. The spatial distribution of DNA and the volume of the bacterium of about $1.6 \mu \mathrm{m}^{3}$ are not inconsistent with this possibility. In view of these considerations an alternative diagram in terms of the mean values, $\overline{\mathrm{L}}_{\infty, \mathrm{D}}$, of unrestricted LET, is added in Fig. 15. With this reference parameter the peaks are still pronounced, but the comparison of the soft $\mathrm{X}$ rays and the protons appears less incoherent.

Possible influence of variations in dose rate has been investigated with $\gamma$ rays. In this part of the experiment it has been found that variations in exposure time between fractions of a minute to more than an hour lead to no observed changes in inactivation probability or mutation frequency in strain TA2638. This is in line with the observed exponential relation for survival and the linear dose dependence for histidine reversions in this strain.

\section{ACKNOWLEDGMENTS}

This study has greatly profited from the dedicated work of Miss Renate Enßer and Miss Petra Wolf. We are especially indebted to the GSF, Munich, and to the GSI, Darmstadt for the utilization of their accelera- 
tor facilities. Essential support for the irradiation experiments at the GSF has been given by Drs. F. Schulz. B. Hietel, and O. Balk. Special thanks are also due to Prof. M. Bauchinger, GSF, for technical help and permission to utilize his laboratory facilities. This work was supported by the Federal Ministry for Environment Protection and Reactor Safety of the Federal Republic of Germany-Contract St. Sch. 956. The responsibility for the results and conclusions remains with the authors.

RECEIVED: December 28, 1987; REVISED: May 17, 1988; RE-REVISED: July 11, 1988

\section{REFERENCES}

1. B. N. AMES, A bacterial system for detecting mutagens and carcinogens. In Mutagenic Effects of Environmental Contaminants (E. Sutton and M. Harris, Eds.), pp. 57-66. Academic Press, New York, 1972.

2. M. ISILDAR and G. BAKALE. Radiation-induced mutagenicity and lethality in Ames tester strains of Salmonella. Radiat. Res. 100, 396-411 (1984).

3. M. IsILDAR and G. BAKALE, Comparative lethal effects of uv and ionizing radiation in Ames tester strains of Salmonella. Radiat. Res. 103, 461-465 (1985).

4. F. P. IMRAY and D. G. MACPHEE, Mutagenesis by ionizing radiation in strains of Salmonella typhimurium used in the Ames test. Int. J. Radiat. Biol. 40,111-115 (1981).

5. H. Roos, W. -H. ThOMAS, and A. M. KelleRER, Enhanced response of the Salmonella mutagenicity test to ionizing radiations. Radiat. Res. 104, 102-108 (1985).

6. R. COX and W. K. MASSON, Mutation and inactivation of cultured mammalian cells exposed to beams of accelerated heavy ions, III. Human diploid fibroblasts. Int. J. Radiat. Biol. 36, Vo. 2, 149-160 (1979).

7. R. J. Munson, G. J. Neary, B. A. Bridges, and R. J. Preston, The sensitivity of Escherichia coli to ionizing particles of different LETs. Int. J. Radiat. Biol. 13, 205-224 (1967).

8. R. J. MUNSON and B. A. BRIDGES, Lethal and mutagenic lesions induced by ionizing radiations in $E$. coli and DNA strand breaks. Biophysik 6, 1-5 (1967).

9. D. M. MARON and B. N. Ames, Revised methods for the Salmonella mutagenicity test. Mutat. Res. 113, 173-215(1983).

10. H. Modler, R. Blohm, K. -P. HermanN, and D. Harder, Photonenspektren, Elektronenspektren und Dosisumrechnungsfaktoren für weiche und ultraweiche Röntgenstrahlung. Medizinische Physik 1984 (Th. Schmidt, Ed.), pp. 375-378. JSBN 3-925218-01-7.

11. H. Roos and A. M. Kellerer, An Irradiation Device for Microbiological Studies with Charged Particle Accelerators. IMSK 87/111, 1987.

12. ICRU, Microdosimetry: Report 36, International Comission on Radiation Units and Measurements, Bethesda, Maryland, 1983.

13. H. Roos and A. M. KellereR, An Alpha-Irradiation Device for Cell Studies. IMSK 86/108, 1986.

14. G. Kraft, H. W. Daues, B. Fischer, U. Kopf, H. P. Liebold, D. Quis, H. Stelzer, J. Kiefer, R. SCHÖPFER, E. SCHNEIDER, U. WEBER, H. WULF, H. DERTINGER, Irradiation chamber and sample changer for biological samples. Nuclear Instrum. Methods 168, 175-179 (1980).

15. J. F. ZIEGLeR, Handbook of Stopping Cross-Sections for Energetic Ions in All Elements. Pergamon, New York, 1980

16. R. J. MUNSON and B. A. BRIDGES, The LET factor in mutagenesis by ionizing radiations I. Reversion to wild type of a bacteriophage T4 amber mutant. Int. J. Radiat. Biol. 24, 257-273 (1973).

17. D. T. GoodHEAD, Biophysical models of radiation action. In Radiation Research (E. M. Fielden, J. F. Fowler, J. H. Hendry, and D. Scott, Eds.), Taylor \& Francis, London, 1987. [Abstract]

18. R. BLOHM and D. HARDER, Restricted LET: Still a good parameter of radiation quality for electrons and photons. Radiat. Protect. Dosim. 13, 377-381 (1985).

19. D. HARDER and R. BLOHM, Microdosimetric characterisation of photon and electron radiations. Radiat. Protect. Dosim. 9, 171-174 (1984). 


\section{Author Index for Volume 116}

A

AkiYAMA, Mitoshi, 343

Alfieri, Alan A., 320, 337

ANG, K. KIAN, 327

Austin, Donald F., 3

AZZAM, E. I., 442

\section{B}

BangraZI, CATERINA, 503

BAUER, KENNETH D., 364

BELL, C. M. JANINE, 3

BELLI, JAMES A., 124

Berrino, Franco, 3

BJÖRKHOLM, ELISABETH, 3

BLEKKENHORST, GERRY H., 539

BLETTNER, MARIA, 3

BLOOM, EDA T., 343

BOICE, JOHN D., JR., 3

BOSCH, ANTONIO, 3

BRABY, L. A., 183

BRENNER, D. J., 172

BRENT, R. L., 416

Burgman, P., 406

\section{C}

CHOI, N. WON, 3

Cleaver, James E., 245

Close, David M., 196, 379

Coleman, Michel P., 3

COOKFAIR, DIANE L., 3

CoPPOLA, MARIO, 503

Covelli, Vincenzo, 503

Debieu, D., 74

DELL, R. B., 263

DeschavanNe, P. J., 74

Dethlefsen, L. A., 228

Dewey, William C., 157

Di MAJO, VinCENZO, 503

Dizdaroglu, Miral, 210

DOLOY, M. T., 254
DORIA, GINO, 503

Drab, Elizabeth A., 364

E

EDWARDS, STEPHEN M., 526

ELLETt, William H., 173

ENGHOLM, GÖRAN, 3

EPP, EDWARD R., 482

F

FELlENZ, MARY PAT, 305

FERTIL, B., 74

FITZEK, M., 292

Flick, MARYANN B., 462

FOWLER, J. F., 175

Fraser, PATRICIA, 3

FRIEDMAN, LIBBY R., 89

FRISCHKORN, ROLF, 3

FRY, R. J. M., 1

\section{G}

GARRISON, JAMES C., 356

GERWECK, LEO E., 305

GORODETSKY, RAPHAEL, 135

GRIEM, M. L., 176

GRUNWALD, D., 254

GUEDENEY, G., 254

GUPTA, VICRAM, 124

H

HAMrICK, PhILliP J., JR., 373

HANSEN, J. W., 547

HANSON, WAYNE R., 145

HAVEN, YSBRAND, 373

HERRLICH, PETER, 178

HISLOP, T. GREGORY, 3

HOFER, K. G., 283

Hole, Eli O., 196

HoNG, SEONG Su, 320

HOWARD, J., 183

HSIEH, CHUNG-CHENG, 482

HutChISON, GEORGE B., 3
J

JEE, W. S. S., 263

JENSH, R. P., 416

JIANG, GUO-LIANG, 327

JOHNSON, F., 263

JONES, SANDRA D., 327

K

Kampinga, HaRM H., 114

KANAI, TATSUAKI, 472

KARAM, LISA R., 210

KELLAND, LLOYD R., 526

KeLleRER, A. M., 292

Kent, Charles R. H., 539

KeyEs, SUSAN R., 100

KIM, JAE Ho, 320, 337

KIM, SANG HIE, 320, 337

KIRN, VERA POMPE, 3

KJORSTAD, KJELL E., 3

Kleinerman, RUth A., 3

Kliauga, P. J., 183

KOCH, MARIA, 3

KONDO, TAKASHI, 56

KoNINGS, A. W. T., 406

KONINGS, ANTONIUS W. T., 114

KORN, EDWARD L., 343

KREIGER, NANCY, 3

KREMENTZ, EDWARD T., 3

KRISCH, ROBERT E., 462

KRISHNA, C. MURALI, 56

KUSUNOKI, YOICHIRO, 343

L

LASZLO, ANDREI, 427

LATOURETTE, HOWARD B., 3

LAUHALA, K. E., 393

LisCo, HeRMANN, 3

LOCHMÜLLER, H., 3

M

MA, YI, 373

MACMAHON, BRIAN, 3 
Makinodan, TaKashi, 343

Malaise, E. P., 74

Malarbet, J. L., 254

MALKINSON, FREDERICK D., 145

MCBRIDE, William H., 135

MCDONALD, K. E., 393

MERRILl, JAMES A., 3

MetTING, N. F., 183

MEYN, RAYMOND E., 217, 511

Milas, LUKa, 327

Moloney, William C., 3

MurRay, DAVID, 511

$N$

Neal, Frank E., 3

Nelson, William H., 196, 379

NENOI, Mitsuru, 472

NGO, FRANK Q. H., 482

\section{O}

Oleinick, NANCY L., 89

Olsen, K. J., 547

$\mathbf{P}$

Panizzon, Renato G., 145

Pejovic, Marie-Hélène, 3

Peters, Lester J., 3, 327

Pettersson, Folke, 3

PollG, E., 263

PREFFER, F. I., 453

Prior, PATRICIA, 3
R

RAAPHORST, G. P., 442

RAMSAY, J., 453

RAPKIN, M., 183

REBESSI, SimONETTA, 503

RiESZ, PETER, 56

RIMPELA, ARJA, 3

ROBB, DOROTHY, 3

ROBERTS, William K., 482

ROBSON, DIANE, 3

ROCKWELL, SARA, 100

RoOS, H., 292

ROSENSTEIN, BARRY S., 313

Rossi, H. H., 183

ROTI Roti, JOSEPH L., 114

ROWLEY, R., 228

Rubin, David B., 364

\section{$\mathrm{S}$}

Sagstuen, Einar, 196, 379

SANDERS, C. L., 393

Sartorelli, Alan C., 100

SCHIMMERLING, W., 183

SCHNEIDERMAN, G. S., 283

SChNeIDERMAN, M. H., 283

SCHULZ, MILFORD D., 3

SCHWARTZ, DAVID E., 145

SEDLACEK, R., 453

SEDLACEK, ROBERT, 482

SHIELDS, HowaRD, 373

SigurdSSON, KRISTJAN, 3

Silver, GEOFFREY, 482

Simic, Michael G., 210

Stankusova, HanNa, 3

Steel, G. Gordon, 526
Storm, Hans H., 3

Stovall, MarilyN, 3

SUIT, H. D., 453

SUIT, Herman D., 482

Sweigert, S. E., 228

\section{$\mathrm{T}$}

THAMES, HOWARD D., 327

THOMAS, W.-H., 292

ThOMSON, D. H., 3

TOFILON, Philip J., 217

U

UYEKI, EDWIN M., 356

V

VANANKEREN, SuSANNa C., 511

VERHEY, LYNN, 482

Vidair, ChARLES A., 157

VON FOURNIER, DIETRICH, 3

\section{w}

WARD, WILLIAM F., 364

WARTERS, R. L., 228

WITHERS, H. RODNEY, 135

WONG, M., 183

Wright, William D., 114

$x$

XUE, LiANG-YaN, 89

Z

ZAIDER, M., 183 


\title{
Cumulative Subject Index ${ }^{1}$
}

\author{
Volumes 113-116
}

A

Acknowledgment

manuscript reviewers, 114, 641

Adenine

formation in $\gamma$-irradiated adenosine 5 -monophosphate solutions, role of oxygen, 113, 447

Adenosine 5'-monophosphate

$\gamma$ irradiation, oxygen dependence of product formation, 113, 447

Adipose tissue

normal, response to graduated doses of hyperthermia (pig), 114, 225

Amino acids

irradiation, dose-response relationships, letter to the editor, 111, 374; reply, 116, 547

3-Aminobenzamide

effect on

cell survival after $\mathrm{X}$ irradiation (CHO HA-1 cells), 114, 186

heat sensitivity of HeLa cells, 116, 406

thermotolerance and heat and radiation responses (V79 cells), 116, 442

4-Aminobenzamide

effect on heat sensitivity of HeLa cells, 116, 406

L- $\alpha$-Amino- $n$-butyric acid hydrochloride

system containing $1.5 \% \mathrm{~L}$-cysteine $\mathrm{HCl}, \mathrm{X}$ irradiation, ESR study of generated radicals, 116 , 373

2-[(Aminopropyl)amino]ethanethiol, see WR-1065

$S$-2-(3-Aminopropylamino)ethylphosphorothioic acid, see WR-2721

Anesthesia

pentobarbital, effects on tumor energy metabolism in vivo, analysis by ${ }^{31} \mathrm{P}$ NMR spectroscopy (mouse), 115, 361

Angiogenesis capillary, in vivo inhibition by hyperthermia, analysis (mouse), 114, 297
Announcements

American Endocurietherapy Society, 11 th Annual Mid-Winter Meeting, Marco Island, Florida, December 1988, 115, 212

American Radium Society, 71st Annual Meeting, St. Thomas, U.S. Virgin Islands, April 1989, 115, 387

American Society for Photobiology, 10th International Congress, Jerusalem, Israel, October-November 1988, 114, 399

Course on Pathologic Effects of Radiation, Bethesda, Maryland, June 1988, 113, 204

European Society for Radiation Biology, 21 st Annual Scientific Meeting, Tel Aviv, Israel, October 1988, 114, 200, 399

European Society for Therapeutic Radiology and Oncology, Seventh Annual Meeting, The Hague, The Netherlands, September 1988, 114, 399

Health Physics Society, Midyear Topical Meeting, San Antonio, Texas, December 1988, 114, 399

Health Physics Society, Thirty-third Annual Meeting, Boston, Massachusetts, July 1988 , 114, 399

Indian Association of Chemotherapists, Fifth Biennial Conference, Bombay, India, February $1989,115,630$

International Conference: Ionizing Radiation and Cancer Epidemiology, Edgbaston, Birmingham, England, July 1989, 116, 551

National Council on Radiation Protection and Measurements, Twenty-fifth Annual Meeting, Washington, D.C., April 1989, 116, 181

Radiation Research Society 37th Annual Meeting and North American Hyperthermia Group 9th Annual Meeting, Seattle, Washington, March 1989, 115, 211

Society for Risk Analysis, Fifth Annual Meeting, Washington DC, October-November 1988, 114, 399

\footnotetext{
' Boldface numbers indicate appropriate volume; lightface numbers indicate pagination.
} 
Workshop on Biomedical Uses of Heavy Ions at BEVALAC, Berkeley, California, March $1989,115,630$

Anserine

radioprotection of bacteriophages $\mathrm{T} 4$ and $\mathrm{P} 22$

Antibiotics against $\gamma$ irradiation inactivation, 114, 319

in management of postirradiation local and systemic infections, review, 115, 1

Antigens

tumor-specific, radiation-induced expression, analysis in cell hybrids (human), 114, 84

$\beta$-Arabinofuranosyladenine

effect on X-ray-induced chromosome damage in plateau-phase $\mathrm{CHO}$ cells: implications for repair and fixation of $\alpha$-potentially lethal damage, 114, 361

I- $\beta$-D-Arabinofuranosylcytosine

detectable sites in DNA, induction by $\mathrm{X}$ and $\gamma$ irradiation, comparison (human), 114, 168

Arabinose

hypertonic, modified blood-brain barrier, uptake of WR-2721 into brain (rat), 115, 303

Argon ions

accelerated, effect on retina (rat), 115, 192

and $X$ rays, sequential exposure of fibroblasts: damage interaction effects as function of cell

Atomic bomb cycle stage (V79 cells), 115, 54

Hiroshima and Nagasaki, $\gamma$ doses, reassessment, 113, 1

Hiroshima, thermoluminescence dosimetry measurements of $\gamma$ radiation by predose technique, 113, 227

Atomic bomb survivors

cancer mortality risk estimates, effect of changes in dosimetry, 114, 437

in Hiroshima, immune responses, assessment, 116, 343

Attenuation coefficients

photon, and dose-spread kernals, relationships, 113, 235

\section{B}

Bacteria

Escherichia coli

radioprotection by cysteamine, mechanisms, 114,550

thy $A$ mutants, $\gamma$-irradiated, effects of dihydrothymine and thymine glycol on pyrimidine salvage and thymineless radiosensitization, 115,617

and wild-type eukaryotes, uv action spectra (254-320 nm), comparison, 114, 307 interactive killing effects between $X$ rays and $u v$ rays or nitrogen mustard, quantitative aspects, 115, 124

Salmonella typhimurium, his $^{+}$reversions induced by various types of ionizing radiation, comparative analysis, 116, 292

Bacteriophages

$\mathrm{T} 4$ and $\mathrm{P} 22$, inactivation by $\gamma$ irradiation, radioprotective effects of ergothioneine, histidine, carnosine, and anserine, 114, 319

\section{BEIR IV Report}

calculational error in risk estimates for lung cancer due to radon, letter to editor, 116, 173

Benzamide

effect on thermotolerance and heat and radiation responses (V79 cells), 116, 442

Beta irradiation

skin, $100 \%$ tumor induction after repeated doses in limited range (mouse), 115, 488

1,3-Bis(2-chloroethyl)-1-nitrosourea

and $X$ rays, additive induction of sister chromatid exchange in brain tumor cells (rat), 115 , 187

Blood-brain barrier

hypertonic arabinose-modified, uptake of WR2721 into brain (rat), 115, 303

\section{Blood flow}

cerebral

changes after $\gamma$ irradiation, analysis in glioma model (rat), 115, 586

local, effect of ionizing radiation-induced emesis (ferret), 114, 537

tumor

effects of inhalational or injectable anesthetics and of neuroleptic, neuroleptanalgesic, and sedative agents (rat), 114, 64

hydralazine-induced reduction after $\mathrm{X}$ irradiation, effect on efficacy of misonidazole and RSU-1069 (mouse), 115, 292

RIF-1, effect of treatment with etomidate and Gibbs clip (mouse), 114, 105

Body temperature

irradiation-induced responses, role of prostaglandins and histamine $\mathrm{H}_{1}$ and $\mathrm{H}_{2}$ receptors (rat), 114, 42

Bone

trabecular, microdistribution and local dosimetry of ${ }^{226} \mathrm{Ra}$ after iv injection (dog), 116, 263

Bone marrow

$\gamma$-irradiated, recovery of hemopoietic and stromal progenitor cells, effect of low dose rate (mouse), 115, 481

tetrachlorcdecaoxide effects after whole-body $\gamma$ irradiation (rat), 115, 115 
transplantation, role in treatment of nuclear accident victims, 113, 205

Book reviews

Innovations in Radiation Oncology, H. R. Withers and L. J. Peters (Eds.), 1988, 116, 176

Radiobiology for the Radiologist, 3rd ed., E. J. Hall, 1988, 116, 175

Brain

area postrema, chronic lesions, effect of radioemetic protection at 24 hours (cat), 114, 77

$\gamma$ irradiation, associated blood flow changes, analysis in glioma model (rat), 115, 586

heavy ion irradiation, subsequent NMR imaging and spectroscopy (rat), 113, 79

local blood flow, effect of ionizing radiation-induced emesis (ferret), 114, 537

WR-272 1 entry across modified blood-brain barrier (rat), 115, 303

$\mathrm{X}$ irradiation, alterations of neuronal chromatic structure (rat), 114, 94

Bromodeoxyuridine

pulse-labeled fibrosarcoma cells, changes in labeling index during radiation treatment (mouse), 116, 453

t-Butanol

influence on sulfhydryl protection and oxygen effect on radiation-induced inactivation of $\mathrm{r}$ chromatin in vitro (Tetrahymena), 115, 141

protective effects on radiation-induced inactivation of isolated transcriptionally active chromatin: influence of secondary radicals (Tetrahymena), 114, 28

L-Buthionine sulfoximine

and dimethylfumarate, acute depletion of glutathione, toxic effects on mammary carcinoma cells (mouse), 114, 215

\section{C}

Caffeine

modulation of X-ray lethal action on fibroblasts (V79 cells), 115, 176

Calcium

dependent cellular processes, induction by hyperthermia, role in thermoresistance (Chinese hamster lung, Morris hepatoma cells), 113,426

intracellular levels

in cells and tissues, relationship to heat shockinduced protein synthesis and cytoskeletal rearrangements (Drosophila melanogaster), 113, 402

effect of hyperthermia (mammalian cells), 113, 414

role in heat-induced cell injury, symposium introduction, 113, 401

\section{Calorimetry}

measurements of carbon kerma factor for 14.6$\mathrm{MeV}$ neutrons, correction, 113, 396; reply. 113, 398

\section{Cancer}

cervical, patients receiving radiotherapy: relationship between dosage and second cancer risk, 116, 3

mortality risk estimates in atomic bomb survivors, effect of changes in dosimetry, 114, 437

relative risk, for radiogenic neoplasms, extrapolation across mouse strains and to man, 114, 331

therapy, potential applicability of nonclonogenic measurements (human), 114, 401

\section{Carcinogenesis}

pulmonary, promotion by plutonium particle aggregation after ${ }^{239} \mathrm{PuO}_{2}$ inhalation (rat), 116 393

radiotherapy-induced, in patients with cervical cancer: relationship between radiation dose and cancer risk, 116, 3

$\mathrm{X}$-ray-induced, effect of hyperthermia (mouse), 115,448

Cardiomyopathy

radiation-induced, analysis (dog), 113, 120

Cardiovascular function

effect of chronic ${ }^{239} \mathrm{PuO}_{2}$ inhalation exposure $(\mathrm{dog}), 115,314$

\section{Carnosine}

radioprotection of bacteriophages T4 and P22 against $\gamma$ irradiation inactivation, 114, 319

\section{Catalase}

increased activity in stable $\mathrm{H}_{2} \mathrm{O}_{2}$-resistant variants of CHO HA-1 cells, analysis, 114, 114

\section{Cataracts}

incidence in patients injected with ${ }^{224} \mathrm{Ra}$, epidemiological analysis, 115, 238

Cell cultures

cerebral gliosarcoma cells in monolayers and spheroids, repair of potentially lethal damage and reentry into cycling phase after $X$ irradiation, comparison (rat), 114, 515

limb bud, chondrogenic development, effects of $\gamma$ radiation (chicken embryo), 116, 356

Cell cycle

effect on X-ray-induced DNA double- and singlestrand breaks, comparison (murine mammary tumor cells), 116, 228

$\mathrm{G}_{2}$ arrest in X-irradiated CHO cells, effects of poly(adenosinediphosphoribose) synthesis inhibitors and structurally related compounds, 113, 58

$\gamma$-ray-sensitive XR-1 cells, role in repair of potentially lethal damage, 115, 325 
progression in aortic endothelial cells after $\gamma$ irraciation, analysis (bovine), 116, 364

quiestence, stimulation of lens epithelial cells fom, subsequent sensitivity to X-ray-incuced growth arrest (rat), 113, 133

selectve ${ }^{125}$ I irradiation of DNA during, effects (n cell progression (CHO cells), 116, 283

$S$ phase, delay in initiation of DNA synthesis after irradiation, effect of oxygen (murine melcnoma), 113, 102

stage-dependent influence on damage interaction iffects after sequential exposures to highind low-LET radiations (V79 cells), 115, 54

synctronized neuroblastoma cells, proliferation ifter heat treatment, role of heat-shock proeins (mouse), 113, 252

syncironous $\mathrm{Gl}$ and $\mathrm{S}$ phase $\mathrm{CHO}$ cells, hyperhermic cell killing in vitro, time-temperaure analyses, 113, 318

$\mathrm{X}$-irradiated cerebral gliosarcoma cells grown as monolayers and spheroids, comparative

Cell killing malysis (rat), 114, 515

hyperthermic

CHO cells in plateau phase, analysis of rapid and slow modes, 116, 157

efiect of pentamidine (HeLa cells), 116, 320

hypoxic glucose-deprived HeLa cells, protection by purine ribonucleosides, 116, 337

ard mitogenic response to serum and growth factors, relationship (CHO HA-1 cells), 113, 501

rcle of

$\mathrm{Ca}^{2+}$, symposium introduction, 113, 401

poly(ADP-ribose)polymerase (HeLa cells), 116, 406

and serum starvation, effect on viability of CHO HA-1 cells, 113,513

sinchronous $\mathrm{Gl}$ and $\mathrm{S}$ phase $\mathrm{CHO}$ cells in vitro, time-temperature analyses, 113, 318

induced by $N$-methyl- $N^{\prime}$-nitro- $N$-nitrosoguanidine, effect of $\gamma$ preirradiation (V79 cells), 115,609

leukemia cells by very low dose rate $\gamma$ irradiation (mouse), 115, 273

RIF-1 tumor cells with 8-hydroxyquinoline, evaluation (mouse), 115, 373

Cell lines, see also Tumor cells

023 (Chinese hamster lung), thermoresistance, role of hyperthermia-induced $\mathrm{Ca}^{2+}$-dependent cellular responses, 113, 426

AA8 (Chinese hamster ovary), and radiosensitive clones

DNA strand breaks, induction and rejoining after $\gamma$ irradiation, 116, 511 survival and recovery after $\gamma$ irradiation, $\mathbf{1 1 5}$, 223

$A_{L}$ (human $\times$ hamster hybrid), neutron irradiation, mutation induction and relative biological effectiveness, 115, 281

CC91 (human fibroblasts), infection with $\gamma$-irradiated simian virus 40: intracellular induction and repair of viral DNA strand breaks, analysis, 116, 462

CGL1 (HeLa $\times$ skin fibroblasts), radiation-induced expression of tumor-specific antigen, analysis, 114, 84

$\mathrm{CHO}$ (Chinese hamster ovary), see $\mathrm{CHO}$ cells

$\mathrm{CV}-1$ (African green monkey kidney), infection with $\gamma$-irradiated simian virus 40: intracellular induction and repair of viral DNA strand breaks, analysis, 116, 462

HeLa (human cervical carcinoma), see HeLa cells

Kc (Drosophila melanogaster), intracellular free $\mathrm{Ca}^{2+}$ levels, relationship to heat shock-induced protein synthesis and cytoskeletal rearrangements, 113, 402

L5178Y-R and L5178Y-S (murine lymphoblastic leukemia), radiosensitivity and repair of potentially lethal and sublethal damage, effects of reduced temperature and starvation conditions, 113, 458

TN-368 (Trichoplusia ni)

$\gamma$-irradiated, recovery enhancement by splitdose treatment, 115, 413

radiosensitivity and DNA double-strand break repair, comparison, 113, 268

V79 (Chinese hamster lung fibroblasts), see V79 cells

XR-1 (Chinese hamster ovary), $\gamma$-ray-sensitive, cell cycle-dependent repair of potentially lethal damage, 115, 325

Cervix

cancer patients, risk of radiotherapy-induced carcinogenesis and radiation dose, relationship, 116, 3

Chemosensitivity

tumor cells, assessment techniques, implications for clinical oncology (human), 114, 401

\section{Chimeras}

embryo aggregation, assay for $\mathrm{X}$-ray-induced nonlethal changes in preimplantation embryos (mouse), 113, 289

Chloral hydrate

effect on tumor blood flow (rat), 114, 64

CHO cells

DNA, selective ${ }^{125}$ I irradiation during cell cycle, effects on cell progression, 116, 283 
DNA synthesis, heat effects, assessment of subsequent recovery, 114, 125

$G_{2}$ arrest induced by $X$ irradiation, effects of poly(adenosinediphosphoribose) synthesis inhibitors and structurally related compounds, 113, 58

$\gamma$-ray-induced DNA single-strand breaks, radioprotective effects of WR-1065, 113, 155

HA-1

heat-resistant variants, heat-shock protein synthesis regulation, analysis, 116, 427

hyperthermic cell killing

and serum starvation, effect on viability, 113,513

subsequent mitogenic response to serum and growth factors, 113, 501

stable $\mathrm{H}_{2} \mathrm{O}_{2}$-resistant variants, increase in catalase activity, 114, 114

survival after $X$ irradiation, effects of sodium butyrate and 3-aminobenzamide, 114, 186

viability during serum starvation and hyperthermia, 113, 513

heating at $45^{\circ} \mathrm{C}$ at $\mathrm{pH} 6.6$

development of thermotolerance and changes in intracellular $\mathrm{pH}, \mathbf{1 1 5}, 106$

relationship between intra- and extracellular $\mathrm{pH}, \mathbf{1 1 5}, 96$

heat-sensitive thermotolerant defective mutants, isolation and characterization, 113, 526

hyperthermia-induced death in plateau phase, analysis of rapid and slow modes, 116, 157

hyperthermic radiosensitization, acid-induced increase, role of intracellular and extracellular $\mathrm{pH}, \mathbf{1 1 5}, 576$

intracellular $\mathrm{pH}$ and cell energy status, effect of extracellular $\mathrm{pH}$ : relationship to hyperthermic sensitivity, 116, 305

microinjection with glutathione disulfide, induction of thermotolerance, 115, 202

mitochondrial damage after hyperthermic exposures, electron microscopic analysis, 115 , 421

mitochondrial glutathione depletion, relationship to thermal sensitivity, 115, 461

oxygen uptake, inhibition by lonidamine, 113, 356

plateau-phase, X-ray-induced chromosome damage, effect of arabinofuranosyladenine, implications for repair and fixation of $\alpha$-potentially lethal damage, 114, 361

protein synthetic mutant and wild-type cells, $X$ irradiation: analysis of split-dose recovery and protein synthesis, 114, 281

radiosensitivity, effect of dimethylfumarate, 115, 495 sensitization to hyperthermia, role of low intracellular $\mathrm{pH}, 114,154$

synchronous GI and S phase, hyperthermic cell killing in vitro, time-temperature analyses, 113, 318

Chondrogenesis

limb bud cells in vitro, effects of $\gamma$ radiation (chicken embryo), 116, 356

Chromatids

sister, exchange in brain tumor cells, additive induction by $X$ rays and 1,3-bis(2-chloroethyl)-1-nitrosourea (rat), 115, 187

\section{Chromatin}

cerebellar neuronal, postirradiation structural alterations, analysis (rat), 114, 94

damage in $\gamma$-irradiated V79 cells, repair, effects of glutathione depletion and hypoxia, 116, 89

isolated transcriptionally active, radiation-induced inactivation, protection by $\mathrm{OH}$ scavengers: influence of secondary radicals ( $T e t$ rahymena), 114. 28

radiation-induced inactivation in vitro, sulfhydryl protection and oxygen effect, influence of $t$-butanol (Tetrahymena), 115, 141

thymic, conformational changes after microwave exposure (rabbit), 115, 44

\section{Chromosomes}

damage by $\gamma$ irradiation, comparison between human and murine peripheral blood lymphocytes, 115, 334

and DNA

initial damage after $\mathrm{X}$ irradiation, role in radiosensitivity difference between L5178Y-R and L5178Y-S cells (mouse), 115, 550

repair after $\mathrm{X}$ irradiation, role in radiosensitivity difference between L5178Y-R and L5178Y-S cells (mouse), 115, 566

$\gamma$-ray- and fission-spectrum neutron-induced damage, radioprotective effects of WR-1065 (V79 cells), 113, 145

lymphocyte, structural aberrations induced by acute and fractionated $\gamma$ irradiation, time dependence (human, monkey), 116, 254

in peripheral lymphocytes of Hodgkin's disease patient, structural aberrations induced by radiotherapy, 114,528

transposon- and X-ray-induced translocations and transmission distortion, interaction (Drosophila melanogaster), 115, 503

$\mathrm{X}$-ray-induced damage

long-term repair in vivo (murine hepatocytes), 113, 40

in plateau-phase $\mathrm{CHO}$ cells, effects of arabinofuranosyladenine: implications for repair 
and fixation of $\alpha$-potentially lethal damage, 114,361

Cisplatin

oxygen- and temperature-dependent cytotoxic and radiosensitizing effects on cervical carcinoma cells in vitro (human), 114, 489

Clonogens

hepatocyte, sensitivity to X-ray dose fractionation (mouse), 113, 51

Coions

depletion near DNA: evidence from DNA interaction with glutathione and other low-molecular-weight thiols, 114, 3

Collagen

biosynthesis in skin and skin fibroblast cultures, $\gamma$-ray-induced increases, 48-week study (mouse), 116, 145

isotypes I, III, and IV in lung, changes induced by $\mathrm{X}$ irradiation, effects of time, dose, and WR-2721 (mouse), 115, 515

Colony-forming ability

hepatocytes after $\mathrm{X}$ irradiation, long-term repair in vivo (mouse), 113, 40

Computer simulation

Monte Carlo method, track structures for 0.3$20-\mathrm{MeV}$ protons, microdosimetric aspects, 115, 389

Copper

serum levels, evaluation as index of lung injury after hemithorax exposure to $\gamma$ rays (rat), 114, 613

Cordycepin

and 2-halo derivatives, metabolic effects on repair of X-ray-induced potentially lethal damage in V79 cells, 114. 231

Counterions

condensation near DNA: evidence from DNA interaction with glutathione and other lowmolecular-weight thiols, 114, 3

$8,5^{\prime}$-Cycloadenosine 5'-monophosphate

formation in $\gamma$-irradiated adenosine $5^{\prime}$-monophosphate solutions, role of oxygen, 113, 447

Cysteamine

radioprotection of Escherichia coli, mechanisms, 114, 550

Cytoskeleton

rearrangements, heat shock-induced, in cells and tissues, relationship to intracellular free $\mathrm{Ca}^{2+}$ levels (Drosophila melanogaster), 113, 402

Cytotoxicity

cis-dichlorodiammineplatinum(II) against cervical carcinoma cells in vitro, analysis (human), 114, 489

\section{Damage}

chromosomes, $\gamma$-ray- and fission-spectrum neutron-induced, radioprotective effects of WR1065 (V79 cells), 113, 145

DNA

induction and repair in $\gamma$-irradiated lymphoblasts, effects of oxygen and misonidazole (human), 115, 436

in irradiated epithelial teratocarcinoma cells, comparison with V79 cells (human), 113, 278

potentially lethal, see Potentially lethal damage sublethal, see Sublethal damage

3'-Deoxyadenosine, see Cordycepin

Deoxyribose

moiety in oligo- and polydeoxynucleotides, $\mathrm{H}$ atom abstraction by thymine radicals, analysis, 116, 210

Development

reflex acquisition and physiologic marker appearance, effects of prenatal $\mathrm{X}$ irradiation (rat), 116, 416

\section{Diazepam}

effect on tumor blood flow (rat), 114, 64

cis-Dichlorodiammineplatin, see Cisplatin

Diethyldithiocarbamate

radiosensitization of tumors in vivo (mouse), 116, 539

Differentiation

cellular, effect on repair of DNA damage in uvirradiated proadipocytes (mouse), 116, 217

$\alpha$-Difluoromethylornithine

induced polyamine depletion, effects on radiosensitivity of colon carcinoma cells (human), 114, 634

Dihydrothymine

effect on pyrimidine salvage and thymineless radiosensitization in Escherichia coli thyA cells, 115, 617

Dimethylfumarate

and L-buthionine sulfoximine, acute depletion of glutathione, toxic effects on mammary carcinoma cells (mouse), 114, 215

effect on $\mathrm{CHO}$ cell sensitivity to $\mathrm{X}$ irradiation, 115, 495

16,16-Dimethylprostaglandin $E_{2}$

and/or WR-2721, radioprotection against fission neutron- $\gamma$ irradiation (mouse), 115, 605

Disease

incidence in $\mathrm{C} 57 \mathrm{Bl}$ mouse after single and fractionated $\gamma$ and neutron irradiations, 113, 300 


\section{DNA}

and chromosomes

initial damage after $X$ irradiation, role in radiosensitivity difference between L5178Y-R and L5178Y-S cells (mouse), 115, 550

repair after $\mathrm{X}$ irradiation, role in radiosensitivity difference between L5178Y-R and L5178Y-S cells (mouse), 115, 566

damage

induced by uv irradiation, effect of cellular differentiation on repair (mouse), 116, 217

induction and repair in $\gamma$-irradiated lymphoblasts, effects of oxygen and misonidazole (human), 115, 436

in irradiated epithelial teratocarcinoma cells, comparison with V79 cells (human), 113, 278

double-strand breaks

induction and rejoining in cervical carcinoma cells of differing radiosensitivity after $\gamma$ irradiation (human), 116, 526

repair

in eukaryotic cells with different radiosensitivities (Trichoplusia ni, V79 cells), 113, 268

in $\gamma$-ray-sensitive XR-1 cells, cell cycle dependence, 115, 325

inhibition by SR-4077 (CHO cells), 113, 346; erratum, 114, 643

resultant exponential or shouldered survival curves, dependence on postirradiation conditions (yeast), 114, 54

$\mathrm{X}$-ray-induced, measurement by neutral filter elution: calibration by ${ }^{125}$ I decay (V79 cells), 115,624

interaction with glutathione and other low-molecular-weight thiols: evidence for counterion condensation and coion depletion near DNA, 114, 3

irradiated with $\gamma$ or uv rays, cleavage by Micrococcus luteus $\gamma$-endonuclease, analysis, 114, 556

nuclear, supercoiling, interactive effects of heat and $\gamma$ irradiation (HeLa cells), 116, 114

processing at nuclear matrix, blockage by hyperthermia (HeLa cells), 115, 258

-protein crosslinks, repair in $\gamma$-irradiated V79 cells, effects of glutathione depletion and hypoxia, 116, 89

radioprotection by thiols, relationship to thiol net charge, 114, 11

redoxy-endonuclease-mediated cleavage at sites of uv-induced photoproducts, wavelength dependence (human), 113, 543 repair patches, normal and xeroderma pigmentosum fibroblasts, proximity to persistent pyrimidine dimers, analysis (human), 116, 245 selective ${ }^{125}$ I irradiation during cell cycle, effects on cell progression ( $\mathrm{CHO}$ cells), 116, 283

simian virus $40, \gamma$ irradiation and subsequent cell infection: intracellular induction and repair of strand breaks, analysis (CC91, CV-1 cells), 116, 462

single-strand breaks

$\gamma$-ray-induced, radioprotective effects of WR1065 (CHO cells), 113, 155

induction in fibroblasts by solar uv irradiation, analysis (human skin), 116, 313

induction and rejoining in jejunal cells, effects of radioprotectants WR-2721 and WR-1065 in vivo (mouse), 114, 268

strand breaks

and $1-\beta$-D-arabinofuranosylcytosine detectable sites induced by $X$ and $\gamma$ irradiation, comparison (human), 114, 168

calculation from average doses to small doses, comments, 114, 192

hyperthermic induction, role of poly(ADP-ribose)polymerase (HeLa cells), 116, 406

induction and rejoining in AA8 cells and radiosensitive clones after $\gamma$ irradiation, 116 , 511

$\mathrm{X}$-ray-induced, cell cycle effect, comparison (murine mammary tumor cells), 116, 228

DNA polymerase

heat-induced loss in $\mathrm{CHO}$ cells, acid-induced increase, role of intracellular and extracellular $\mathrm{pH}, 115,576$

DNA synthesis

in $\mathrm{CHO}$ cells, heat effects, assessment of subsequent recovery, 114, 125

delay in initiation after irradiation, effect of oxygen (murine melanoma), 113, 102

in lens epithelial cells

after irradiation with single and fractionated doses of $\mathrm{X}$ rays and neutrons, comparison (mouse), 114, 567

stimulated from quiescence, sensitivity to $\mathrm{X}$ ray-induced growth arrest (rat), 113, 133

Dosage

limited range, in repeated $\beta$ irradiation of skin, $100 \%$ tumor induction (mouse). 115, 488

lung $X$ irradiation, effects on changes in collagen isotypes I, III, and IV (mouse), 115, 515

in radiotherapy of patients with cervical cancer, relationship to second cancer risk, 116, 3 
Dose fractionation

neutron, effect on oncogenic transformation of fibroblasts (mouse), 114, 589; erratum, 116, 550

$\mathrm{X}$-ray, sensitivity of hepatocyte clonogens (mouse), 113, 51

Dose rate

effects on $\gamma$-irradiated normal and malignant cells, in vitro analysis (human), 114, 415

low, effect on recovery of $\gamma$-irradiated hemopoietic and stromal progenitor cells in bone marrow (mouse), 115, 481

very low, $\gamma$ irradiation, mutation induction in leukemia cells (mouse), 115, 273

Dose-response relationships

in irradiation of amino acids, letter to the editor, 111, 374; reply, 116, 547

prenatal $\mathrm{X}$ irradiation effects on appearance of reflexes and physiologic markers (rat), 116 . 416

split-dose sparing of $\gamma$-ray-induced pulmonary endothelial dysfunction (rat), 114, 627

thresholds in radiation exposure responses, letter to editor, 116, 172

Dose-spread kernals

and attenuation coefficients, relationships, 113, 235

Dosimetry

changes in, effect on cancer mortality risk estimates in atomic bomb survivors, 114, 437

local, ${ }^{226} \mathrm{Ra}$ in trabecular bone after iv injection (dog), 116, 263

low-dose-rate irradiation of V79 cells: radiosensitivity enhancement by moderate hyperthermia, 114, 379

micro, see Microdosimetry

neutron and $\gamma$ irradiation, effects of 60 onceweekly exposures, 115,347

thermal, assessment for normal muscle and adipose tissues (pig), 114, 225

thermoluminescence

$\gamma$ doses from atomic bombs in Hiroshima and Nagasaki, reassessment, 113, 1

measurements of $\gamma$ radiation from atomic bomb at Hiroshima by predose technique, 113, 227

very small doses per fraction of $\mathrm{X}$ or neutron radiation, effect on kidney (mouse), 114, 385

Droperidol

effect on tumor blood flow (rat), 114, 64

with Fentanyl, effect on tumor blood flow (rat), 114, 64

\section{E}

Editorial

guest, thresholds in radiation exposure responses,

114, 1

Electron nuclear double resonance

and ESR spectroscopy

GMP single crystals $X$-irradiated at $10^{\circ} \mathrm{K}, 116$, 196

secondary radical formation and reaction mechanisms in X-irradiated single crystals of guanine hydrochloride monohydrate, 116, 379

Electrons

low-energy, in polyatomic gases, mean energy required for ion pair formation, 115, 213

penetration, multiple scattering analysis, 115, 26 subexcitation, absolute scattering probabilities in condensed water, determination, 114, 467

Electron scattering

absolute probabilities for subexcitation electrons in condensed water, determination, 114, 467

multiple, analysis of penetration, 115, 26

Electron spin resonance

in analysis of radicals generated in $\mathrm{X}$-irradiated $\mathrm{L}-\alpha$-amino- $n$-butyric acid $\mathrm{HCl}$ containing $1.5 \%$ L-cysteine $\mathrm{HCl}, 116,373$

and ENDOR spectroscopy

GMP single crystals $X$-irradiated at $10^{\circ} \mathrm{K}, 116$, 196

secondary radical formation and reaction mechanisms in X-irradiated single crystals of guanine hydrochloride monohydrate, 116, 379

spin-trapping study of $\mathrm{H}_{2} \mathrm{O}_{2}$ photolysis, $\gamma$ radiolysis, and sonolysis of pyrimidine derivatives in aqueous solutions, 116, 56

Embryo

preimplantation, $\mathrm{X}$ - ray - induced nonlethal changes, assay with embryo aggregation chimeras (mouse), 113, 289

Emesis

$\gamma$-radiation-induced, effects of zacopride (rhesus monkey), 115, 595

radiation-induced

characterization (ferret), 114, 599

effect on local cerebral blood flow (ferret), 114, 537

$\gamma$-Endonuclease

Micrococcus luteus, cleavage of $\gamma$ - or uv-irradiated DNA, analysis, 114, 556

ENDOR, see Electron nuclear double resonance 
Endothelial cells

aortic, cell cycle progression after $\gamma$ irradiation, analysis (bovine), 116, 364

capillary, hyperthermia effect in vivo (mouse), 114, 297

pulmonary, dysfunction after hemithorax exposure to $\gamma$ rays, split-dose sparing (rat), 114, 627

umbilical cord vein, response to $\gamma$ irradiation, in vitro analysis (human), 114, 415

Energy status

cellular, effect of extracellular $\mathrm{pH}$ : relationship to hyperthermic sensitivity (CHO cells), 116, 305

Epidemiology

cataract incidence in patients injected with ${ }^{224} \mathrm{Ra}$, 115,238

Epithelial cells

alveolar type 2, replicative activity, enhancement by methylprednisolone in radiation pneumonitis (mouse), 115, 543

lens, recovery from single and fractionated doses of $X$ rays and neutrons, comparison (mouse), 114, 567

Ergothioneine radioprotection of bacteriophages T4 and P22 against $\gamma$ irradiation inactivation, 114, 319

Erythrocytes

protein shedding after microwave irradiation, chromatographic analysis (human), 114, 500

ESR, see Electron spin resonance

Etomidate

effect on

RIF-1 tumor radiosensitivity (mouse), 114, 105

tumor blood flow (rat), 114, 64

Eukaryotes

wild-type, and Escherichia coli, uv action spectra (254-320 nm), comparison, 114, 307

Eye

lens epithelial cells stimulated from quiescence, sensitivity to $\mathrm{X}$-ray-induced growth arrest (rat), 113, 133

\section{$F$}

Fentanyl

with fluanisone or droperidol, effect on tumor blood flow (rat), 114, 64

Fibroblasts

dermal

collagen biosynthesis, $\gamma$-ray-induced increases, 48-week study (mouse), 116, 145

DNA single-strand breaks induced by solar uv irradiation, analysis (human), 116, 313
DNA strand breaks and 1- $\beta$-D-arabinofuranosylcytosine detectable sites induced by $\mathrm{X}$ and $\gamma$ irradiation, comparison (human), 114, 168

in exponential growth phase, correlation between survival curve and potentially lethal damage repair capacity (human), 116, 74

intracellular $\mathrm{Ca}^{2+}$ levels and inositol lipid metabolism, effects of hyperthermia (BALB/c 3T3 mouse, Chinese hamster), 113, 414

normal and xeroderma pigmentosum, DNA, proximity of repair patches to persistent pyrimidine dimers, analysis (human), 116, 245

oncogenic transformation by fractionated doses of neutrons, analysis (mouse), 114, 589; erratum, 116, 550

radiosensitivity, enhancement by moderate hyperthermia at low ${ }^{137} \mathrm{Cs}$ irradiation dose rates (Chinese hamster), 114, 379

repair of X-ray-induced potentially lethal damage, metabolic effects of cordycepin and 2halo derivatives (Chinese hamster), 114, 231 response to $\gamma$ irradiation, in vitro analysis (human lung, skin), 114, 415

sensitivity to acute uv exposures, alteration by multiple small far- or mid-uv light exposures, measurement by cell lethality and mutagenesis (Chinese hamster), 114, 248

Filter elution

neutral, in measurement of X-ray-induced DNA double-strand breaks: calibration by ${ }^{125} \mathrm{I} \mathrm{de}-$ cay (V79 cells), 115, 624

Fluanisone

with Fentanyl, effect on tumor blood flow (rat), 114,64

Formate ions

protective effects on radiation-induced inactivation of isolated transcriptionally active chromatin: influence of secondary radicals ( $\mathrm{Tet}$ rahymena), 114, 28

\section{G}

Gamma irradiation

AA8 cells and radiosensitive clones

DNA strand break induction and rejoining, 116, 511

survival and recovery, 115, 223

adenosine 5'-monophosphate, oxygen dependence of product formation, 113, 447

aortic endothelial cells, effect on cell cycle progression (bovine), 116, 364

bacteriophages $\mathrm{T} 4$ and $\mathrm{P} 22$, induced inactivation, radioprotective effects of ergothioneine, histidine, carnosine, and anserine, 114, 319 
bone marrow, recovery of hemopoietic and stromal progenitor cells, effect of low dose rate (mouse), 115, 481

brain, associated blood flow changes, analysis in glioma model (rat), 115, 586

C57 Bl mouse, single and fractionated doses, lifeshortening and disease incidence, 113, 300

cell hybrids, induced expression of tumor-specific antigen, analysis (human), 114, 84

cervical carcinoma cells of differing radiosensitivity, DNA double-strand break induction and rejoining (human), 116, 526

CHO cells, induction of DNA single-strand breaks, radioprotective effects of WR-1065, 113, 155

continuous long-term, diploid yeast culture, associated mitotic recombination, 113, 71

DNA, subsequent cleavage by Micrococcus luteus $\gamma$-endonuclease, analysis, 114, 556

dosages from atomic bombs in Hiroshima and Nagasaki, reassessment, 113, 1

epithelial teratocarcinoma cells, DNA damage and survival parameters, comparison with V79 cells (human), 113, 278

Escherichia coli

radioprotection by cysteamine, mechanisms, 114, 550

thy $A$ mutants, effects of dihydrothymine and thymine glycol on pyrimidine salvage and thymineless radiosensitization, 115, 617

fibrosarcoma, radiosensitivity of late recurrences (mouse), 113, 334

HeLa cells, and heat exposure, interactive effects on nuclear DNA supercoiling, 116, 114

hemithorax

induced lung injury, serum copper levels as index, evaluation (rat), 114, 613

induced pulmonary endothelial dysfunction, split-dose sparing (rat), 114, 627

hepatocytes, comparative radiosensitivity (human, rat), 115, 152

hind thigh, tissue repair and repopulation in tumor bed effect (mouse), 114, 621

human cell lines, induction of DNA strand breaks and $1-\beta$-D-arabinofuranosylcytosine detectable sites, 114, 168

induced emesis, characterization (ferret), 114, 599

induced hypothermia, opposite effects of WR2721 and WR-1065: correlation with oxygen uptake (guinea pig), 114, 240

induced temperature responses, role of prostaglandins and histamine $\mathrm{H}_{1}$ and $\mathrm{H}_{2}$ receptors (rat), 114, 42 jejunum, radioprotection by WR-2721 and WR1065 in vivo: effects on DNA strand break induction and rejoining (mouse), 114, 268

kidney, subsequent characterization of abnormal nuclei in proximal tubular cells (mouse), 115,161

leukemia cells at very low dose rate, mutation induction (mouse), 115, 273

limb bud cells in vitro, effects on chondrogenic development (chicken embryo), 116, 356

lung, induced pneumonitis, replicative activity of alveolar type 2 cells, enhancement by methylprednisolone (mouse), 115, 543

lymphoblasts, induction and repair of DNA damage, effects of oxygen and misonidazole (human), 115, 436

lymphocytes, chromosomal aberrations induced by acute and fractionated exposure, time dependence (human, monkey), 116, 254

mice

effects of 60 once-weekly exposures, 115, 347

tumor induction: relative risk extrapolation across mouse strains and to man, 114, 331

-neutron irradiation, whole-body, radioprotection with WR-2721 and/or 16,16-dimethylprostaglandin $\mathrm{E}_{2}$ (mouse), 115, 605

normal and malignant cells in vitro, analysis of radiation response characteristics (human), 114, 415

peripheral blood lymphocytes, interspecific cytogenetic comparison of responses (human, mouse), 115, 334

prenatal, effects on developing immune system (dog), 115, 472

simian virus 40 , and subsequent cell infection: intracellular induction and repair of DNA strand breaks, analysis (CC91, CV-1 cells), 116, 462

thorax, induction of

collagen biosynthesis increases: 48-week study in skin and skin fibroblast cultures (mouse), 116, 145

pneumonitis, protective effects of corticosteroids (mouse), 113, 112

thymus, effects on nonlymphoid components in vitro $(\mathrm{dog}), 115,84$

TN-368 cells, recovery enhancement by splitdose treatment, 115, 413

tumor cells, radiocurability, effects of $N$-methylformamide (mouse), 113, 199

in utero and postpartum treatments, assessment of prenatal and early postnatal mortality (dog), 115, 70 
V79 cells

effect on sensitivity to $N$-methyl- $N$-nitro- $N$-nitrosoguanidine, 115, 609

induction of chromosome damage, radioprotective effects of WR-1065, 113, 145

subsequent repair of chromatin damage, effects of glutathione depletion and hypoxia, 116,89

and treatment with hypertonic phosphatebuffered saline: estimation of interaction function $\gamma(x), 116,472$

whole-body

induced emesis, effects of zacopride (rhesus monkey), 115, 595

subsequent regenerative effects of tetrachlorodecaoxide (rat), 115, 115

XR-1 cells, cell cycle-dependent repair of potentially lethal damage, 115, 325

\section{Gamma radiation}

from atomic bomb at Hiroshima, thermoluminescence dosimetry by predose technique, 113, 227

Gases

polyatomic, low-energy photons and electrons in, mean energy required for ion pair formation, 115, 213

Gibbs clip

effectiveness in RIF-1 tumor treatment, evaluation (mouse), 114, 105

\section{Glucose}

deprived hypoxic HeLa cells, hyperthermic killing, protection by purine ribonucleosides, 116, 337

Glutathione

acute depletion by L-buthionine sulfoximine and dimethylfumarate, toxic effects on mammary carcinoma cells (mouse), 114, 215

content in colon tumor cells, changes after exposure to sodium butyrate (human), 114, 579

depletion in

mitochondria, relationship to thermal sensitivity (CHO cells), 115, 461

V79 cells, effect on repair of radiation-induced chromatin damage, 116, 89

interaction with DNA: evidence for counterion condensation and coion depletion near DNA, 114, 3

oxidation in CHO cells by SR-4077, 113, 346; erratum, 114, 643

Glutathione disulfide

microinjection into $\mathrm{CHO}$ cells, induction of thermotolerance, 115, 202

\section{Growth factors}

mitogenic response of CHO HA- 1 cells after hyperthermic cell killing, 113, 501
Guanine hydrochloride monohydrate

single crystals, $\mathrm{X}$ irradiation, formation of secondary radicals, reaction mechanisms, ESR and ENDOR spectroscopy, 116, 379

Guanosine 5'-monophosphate

single crystals $\mathrm{X}$ irradiated at $10^{\circ} \mathrm{K}, \mathrm{ESR} / \mathrm{EN}$ DOR study, 116, 196

\section{H}

Heart

radiation-induced cardiomyopathy, analysis (dog), 113,120

Heat-shock proteins

role of $\mathrm{Ca}^{2+}$, symposium introduction, 113, 401

role in proliferation of synchronized neuroblastoma cells after heat treatment (mouse), 113, 252

synthesis

in cells and tissues, relationship to intracellular free $\mathrm{Ca}^{2+}$ levels (Drosophila melanogaster), 113, 402

regulation in heat-resistant variants of $\mathrm{CHO}$ HA-1 cells, analysis, 116, 427

Heavy ions

high-energy, microdosimetry near trajectory, analysis, 116, 183

HeLa cells

DNA processing at nuclear matrix, blockage by hyperthermia, 115, 258

glucose-deprived hypoxic, hyperthermic killing, protection by purine ribonucleosides, 116, 337

heat sensitivity

effect of pentamidine, 116, 320

role of poly(ADP-ribose)polymerase, 116, 406

intracellular $\mathrm{Ca}^{2+}$ levels and inositol lipid metabolism, effects of hyperthermia, 113, 414

nuclear DNA supercoiling, interactive effects of $\gamma$ irradiation and heat, 116, 114

Hepatocytes

clonogens, sensitivity to X-ray dose fractionation (mouse), 113, 51

colony-forming ability and chromosomal injury, long-term repair in vivo after $\mathrm{X}$ irradiation (mouse), 113, 40

radiosensitivity, comparison between human and rat, 115, 152

Hiroshima

atomic bombs, $\gamma$ doses, reassessment, 113, 1

$\gamma$ radiation from atomic bomb, thermoluminescence dosimetry measurements by predose technique, 113, 227

Histamine receptors

$\mathrm{H}_{1}$ and $\mathrm{H}_{2}$, role in irradiation-induced temperature responses (rat), 114, 42 
Histidine

radioprotection of bacteriophages $\mathrm{T} 4$ and $\mathrm{P} 22$ against $\gamma$ irradiation inactivation, 114, 319

Hodgkin's disease

radiotherapy of affected patient, induction of structural chromosome aberrations in peripheral lymphocytes, 114, 528

Hydralazine

reduction of tumor blood flow after $\mathrm{X}$ irradiation, effect on efficacy of misonidazole and RSU-1069 (mouse), 115, 292

Hydrogen

abstraction from sugar moiety by thymine radicals in oligo- and polydeoxynucleotides, analysis, 116, 210

Hydrogen peroxide

resistant variants, increase in catalase activity (CHO HA-1 cells), 114, 114

8-Hydroxyadenosine 5'-monophosphate

formation in $\gamma$-irradiated adenosine 5 '-monophosphate solutions, role of oxygen, 113, 447

Hydroxyl radicals

various scavengers, protective effects on radiation-induced inactivation of isolated transcriptionally active chromatin: influence of secondary radicals (Tetrahymena), 114, 28

8-Hydroxyquinoline

in tumor-targeted cell killing, evaluation (mouse), 115,373

Hyperthermia

associated cell killing, and mitogenic response to serum and growth factors, relationship (CHO HA-1 cells), 113, 501

blockage of DNA processing at nuclear matrix (HeLa cells), 115, 258

cell killing of synchronous $\mathrm{Gl}$ and $\mathrm{S}$ phase $\mathrm{CHO}$ cells in vitro, time-temperature analysis, 113,318

CHO cells at $45^{\circ} \mathrm{C}$

development of thermotolerance after microinjection with glutathione disulfide, 115, 202

at $\mathrm{pH} 6.6$

development of thermotolerance and changes in intracellular $\mathrm{pH}, \mathbf{1 1 5}, 106$

relationship between intra- and extracellular pH, 115, 96

combined with 8-hydroxyquinoline treatment, in tumor-targeted cell killing, evaluation (mouse), 115, 373

effect on

DNA synthesis, assessment of subsequent recovery (CHO cells), 114, 125 intracellular $\mathrm{Ca}^{2+}$ and inositol lipid metabolism (mammalian cells), 113, 414

$\mathrm{X}$-ray-induced carcinogenesis (mouse), 115, 448

and $\gamma$ irradiation, interactive effects on nuclear DNA supercoiling (HeLa cells), 116, 114

graduated doses, responses of normal muscle and adipose tissues (pig), 114, 225

induced cell death of plateau-phase $\mathrm{CHO}$ cells, analysis of rapid and slow modes, 116, 157

induced cell injury, role of $\mathrm{Ca}^{2+}$, symposium introduction, 113, 401

induced heat-shock protein synthesis, regulation in heat-resistant variants of $\mathrm{CHO}$ HA-1 cells, 116, 427

induced mitochondrial damage in $\mathrm{CHO}$ cells, electron microscopic analysis, 115, 421

induced radiosensitization of $\mathrm{CHO}$ cells, acid-induced increase, role of intracellular and extracellular $\mathrm{pH}, 115,576$

induction of $\mathrm{Ca}^{2+}$-dependent processes, role in thermoresistance (Chinese hamster lung, Morris hepatoma cells), 113, 426

inhibition of potentially lethal radiation damage repair in normal hamster cells, mouse cells, and transformed mouse cells, 113, 171

irradiation-induced, role of prostaglandins and histamine $\mathrm{H}_{1}$ and $\mathrm{H}_{2}$ receptors (rat), 114, 42

moderate, enhancement of $\mathrm{V} 79$ cell radiosensitivity at low ${ }^{137} \mathrm{Cs}$ irradiation dose rates, 114 , 379

radiofrequency-induced, in vivo inhibition of capillary angiogenesis (mouse), 114, 297

selective killing of glucose-deprived hypoxic HeLa cells, protection by purine ribonucleosides, 116, 337

sensitivity of

$\mathrm{CHO}$ cells, relationship to extracellular $\mathrm{pH}$ effects on intracellular $\mathrm{pH}$ and cell energy status, 116, 305

HeLa cells

effect of pentamidine, 116, 320

role of poly(ADP-ribose)polymerase, 116, 406

V79 cells, role of poly(ADP-ribose)synthetase, 116, 442

sensitization of $\mathrm{CHO}$ cells to, role of low intracellular $\mathrm{pH}, 114,154$

and serum starvation, effect on viability of $\mathrm{CHO}$ HA-1 cells, 113, 513

and starvation conditions, effects on radiosensitivity and repair of potentially lethal and sublethal damage in L5178Y-R and L5178Y-S cells, 113, 458 
treatment of synchronized neuroblastoma cells, subsequent proliferation, role of heat-shock proteins (mouse), 113, 252

and $X$ irradiation, intestine, induction of thermotolerance, effect on time-temperature relationships (mouse), 113, 375

Hypothermia

$\gamma$-ray-induced, opposite effects of WR-2721 and WR-1065, correlation with oxygen uptake (guinea pig), 114, 240

irradiation-induced, role of prostaglandins and histamine $\mathrm{H}_{1}$ and $\mathrm{H}_{2}$ receptors (rat), 114, 42

Hypoxia

effects on repair of radiation-induced chromatin damage in V79 cells, 116, 89

postirradiation, enhancement of tumor cell radiosensitivity: time course and oxygen concentration dependency (hamster, human. mouse), 116, 124

RIF-1 tumor, effect of treatment with etomidate and Gibbs clip, evaluation (mouse), 114, 105

\section{I}

\section{Imaging}

NMR, central nervous system after heavy ion irradiation (rat), 113, 79

Immune responses

alterations in prenatal dogs after $\gamma$ irradiation, 115,472

atomic bomb survivors in Hiroshima, assessment, 116, 343

Infection

postirradiation, local and systemic, management with antibiotics, review, 115, l

Injury

chronic pulmonary, induced by ${ }^{239} \mathrm{PuO}_{2}$ inhalation, effect on cardiopulmonary function (dog), 114, 314

Interaction function $\gamma(x)$

for V79 cells treated with hypertonic phosphatebuffered saline after $\gamma$ or $\mathrm{X}$ irradiation, estimation, 116, 472

Intestine

jejunum, in vivo radioprotection by WR-2721 and WR-1065: effects on DNA strand break induction and rejoining (mouse), 114, 268

preirradiated, thermotolerance, effect on timetemperature relationships (mouse), 113, 375 Iodine ${ }^{125} \mathrm{I}$

decay calibration in labeled DNA for measurement of X-ray-induced double-strand breaks by neutral filter elution (V79 cells), 115,624 selective irradiation of DNA during cell cycle, effects on cell progression (CHO cells), 116 , 283

Ionizing irradiation

bilateral thoracic, associated early structural changes in lung, analysis (sheep), 114, 138

central nervous system, subsequent NMR imaging and spectroscopy (rat), 113,79

colon tumor cells, radiosensitivity, effects of $\alpha$-difluoromethylornithine-induced polyamine depletion (human), 114, 634

DNA, induced double-strand breaks, repair, resultant exponential or shouldered survival curves, dependence on postirradiation conditions, 114, 54

fibrosarcoma

associated changes in bromodeoxyuridine labeling index (mouse), 116, 453

proliferation kinetics during fractionated treatment (mouse), 116, 327

induced emesis, effect on local cerebral blood flow (ferret), 114, 537

induced inactivation of isolated transcriptionally active chromatin, protection by $\mathrm{OH}$ scavengers: influence of secondary radicals (Tetrahymena), 114, 28

melanoma cells, delay in initiation of DNA synthesis, effect of oxygen (mouse), 113, 102

normal and postremectomized cats, radioemetic protection 24 hours after exposure, analysis. 114, 77

r-chromatin in vitro, induced inactivation, sulfhydryl protection and oxygen effect, influence of $t$-butanol (Tetrahymena), 115, 141

Salmonella typhimurium, induction of $\mathrm{his}^{+}$reversions, comparative analysis of different radiation types, 116, 292

thorax, induced cardiomyopathy, analysis (dog), 113,120

V79 cells, low dose rates: enhancement of radiosensitivity by moderate hyperthermia, 114, 379

water ice pulsed with $0.53-\mathrm{MeV}$ electrons, red luminescence emission, 115, 403

Ionizing radiation

high-LET particles, simulated linear track structures, frequency distributions and density functions of distances, 113,437

induced local and systemic infections, management with antibiotics, review, 115, 1

quality factor, redefinition as function of lineal energy, 114, 480

Ion pairs

formation, required mean energy, measurement for low-energy photons and electrons in polyatomic gases, 115, 213 
Kerma factor

carbon, for 14.6-MeV neutrons, calorimetric measurements, correction, 113, 396; reply, 113, 398

Ketamine

with xylazine or midazolam, effect on tumor

Kidney blood flow (rat), 114, 64

$\gamma$ irradiation, subsequent characterization of abnormal nuclei in proximal tubular cells (mouse), 115, 161

response to very small doses per fraction of $X$ or neutron radiation (mouse), 114, 385

\section{L}

Lens

cataract formation, incidence in patients injected with ${ }^{224} \mathrm{Ra}$, epidemiological analysis, 115 , 238

Lesions

area postrema, chronic, effect of radioemetic protection at 24 hours (cat), 114, 77

Leukotrienes

induction of radioprotection of hematopoietic

Life span stem cells (mouse), 113, 388

reduction in C57Bl mouse after single and fractionated $\gamma$ and neutron irradiations, 113 , 300

shortening in

$\mathrm{BC} 3 \mathrm{~F}_{1}$ mice after low-dose neutron and $\mathrm{X}$ irradiation, 113, 362

$\mathrm{B} 6 \mathrm{CF}_{1}$ mice after neutron and $\gamma$ irradiation, effects of 60 once-weekly exposures, 115, 347

\section{Lineal energy}

in ionizing radiation, relationship to quality factor, 114, 480

Lonidamine

inhibition of cellular oxygen utilization $(\mathrm{CHO}$, FSa-II cells), 113, 356

Luminescence

red emission from electron-pulsed water ice, 115 , 403

Lung

alveolar type 2 cells, replicative activity, enhancement by methylprednisolone in radiation pneumonitis (mouse), 115, 543

carcinogenesis, promotion by plutonium particle aggregation after ${ }^{239} \mathrm{PuO}_{2}$ inhalation (rat), 116, 393

chronic ${ }^{239} \mathrm{PuO}_{2}$ inhalation injury, effect on cardiopulmonary function $(\mathrm{dog}), 115,314$ collagen isotypes I, III, and IV, changes after X irradiation, effects of time, dose, and WR2721 (mouse), 115, 515

early structural changes after thoracic irradiation, analysis (sheep), 114, 138

endothelial dysfunction after hemithorax exposure to $\gamma$ rays, split-dose sparing (rat), 114, 627

injury after hemithorax exposure to $\gamma$ rays, serum copper levels as index, evaluation (rat), 114,613

metastases of B16 melanoma, comparative effects of daily and weekly fractions of $\mathrm{X}$ irradiation (mouse), 114, 354

Lymphoblasts

$\gamma$-irradiated, induction and repair of DNA damage, effects of oxygen and misonidazole (human), 115, 436

L5178Y-R and L5178Y-S leukemic, difference in radiosensitivity, role of

DNA and chromosome repair (mouse), 115, 566

initial DNA and chromosome damage (mouse), 115,550

Lymphocytes

chromosomal aberrations induced by acute and fractionated $\gamma$ irradiation, time dependence (human, monkey), 116, 254

peripheral blood

in Hodgkin's disease patient, structural chromosome aberrations induced by radiotherapy, 114, 528

responses to $\gamma$ irradiation, interspecific cytogenetic comparison (human, mouse), 115, 334

Lymphoid organs

total X irradiation, late somatic effects (mouse), 116, 503

M

Mechlorethamine

and $X$ irradiation, quantitative aspects of interactive killing effects in bacteria, 115, 124

Membranes

thymic, cytoplasmic and nuclear, conformational changes after microwave exposure (rabbit), 115, 44

2-Mercaptoethanol

protection against radiation-induced inactivation of r-chromatin in vitro, effect of $t$-butanol (Tetrahymena), 115, 141

Metastases

pulmonary, B16 ${ }_{\mathrm{a}}$ melanoma, comparative effects of daily and weekly fractions of $\mathrm{X}$ irradiation (mouse), 114, 354 
Methanol

protective effects on radiation-induced inactivation of isolated transcriptionally active chromatin: influence of secondary radicals ( $T e t$ rahymena), 114, 28

Methoxyflurane

effect on tumor blood flow (rat), 114, 64

$\mathrm{N}$-Methylformamide

effect on

oxygen enhancement ratio of colon tumor cells (human), 113, 191

radiocurability of tumor cells (mouse), 113 , 199

$N$-Methyl- $N$ '-nitro- $N$-nitrosoguanidine

V79 cell sensitivity to, effect of $\gamma$ preirradiation, 115, 609

Methylprednisolone

enhancement of alveolar type 2 cell replicative activity in radiation pneumonitis (murine lung), 115, 543

protective effect on radiation pneumonitis (mouse), 113, 112

Microdosimetry

application in radiobiology, 113, 15

near trajectory of high-energy heavy ions, analysis, 116, 183

0.3-20-MeV proton track structures obtained bycomputer simulation, 115, 389

Microwave irradiation

erythrocytes, induction of protein shedding, chromatographic analysis (human), 114, 500

thymus, effect on cellular functional state (rabbit), 115, 44

Midazolam

alone and with ketamine, effect on tumor blood flow (rat), 114, 64

Misonidazole

effects on induction and repair of DNA damage in $\gamma$-irradiated lymphoblasts (human), 115 , 436

plus photons, in fractionated irradiation of spontaneous tumors, therapeutic gain factors (mouse), 116, 482

radiosensitization of tumor cells, enhancement by hydralazine-induced hypoxia after $\mathrm{X}$ irradiation (mouse), 115, 292

Mitochondria

damage in $\mathrm{CHO}$ cells exposed to hyperthermia, electron microscopic analysis, 115, 421

glutathione depletion, relationship to thermal

Models sensitivity (CHO cells), 115, 461

mathematical, subpopulation exclusion in heterogeneous neoplasms caused by tumor bed effect-induced environmental stress, 115, 533

Mortality

cancer-induced, risk estimates in atomic bomb survivors, effect of changes in dosimetry, 114, 437

prenatal and early postnatal, assessment after in utero and postpartum exposure to $\gamma$ radiation (dog), 115, 70

Muscle

normal, response to graduated doses of hyperthermia (pig), 114, 225

Mutagenesis

V79 cells after acute exposures, effects of multiple small far- or mid-uv light exposures, 114, 248

Mutants

heat-sensitive, thermotolerant defective $\mathrm{CHO}$ cells, isolation and characterization, 113 , 526

Mutations

in $A_{L}$ cells, induction by neutron irradiation, 115 , 281

his $^{+}$reversions in Salmonella typhimurium, induction by various types of ionizing radiation, comparative analysis, 116, 292

induced by $N$-methyl- $N^{\prime}$-nitro- $N$-nitrosoguanidine, effect of $\gamma$ preirradiation (V79 cells), 115, 609

in leukemia cells, induction by very low dose rate $\gamma$ irradiation (mouse), 115, 273

\section{$\mathrm{N}$}

$\mathrm{NAD}^{+}$ADP-ribosyltransferase

role in heat sensitivity of HeLa cells, 116, 406

Nagasaki atomic bombs, $\gamma$ doses, reassessment, 113, 1

Natural killer cells

activity against $\mathrm{B} 16_{\mathrm{a}}$ melanoma, comparative effects of daily and weekly fractions of $\mathrm{X}$ irradiation (mouse), 114, 354

Neon ions

and $X$ rays, sequential exposure of fibroblasts: damage interaction effects as function of cell cycle stage (V79 cells), 115, 54

Neoplasms

radiogenic, relative risk extrapolation across mouse strains and to man, 114, 331

Neurons

cerebellar, chromatin structure, postirradiation alterations, analysis (rat), 114, 94

Neutron irradiation

$A_{L}$ cells, mutation induction and relative biological effectiveness, 115, 281 
$\mathrm{BC} \mathrm{F}_{1}$ mouse, at low dosage, tumor induction and life-shortening, 113, 362

C57Bl mouse, single and fractionated doses, lifeshortening and disease incidence, 113, 300

epithelial teratocarcinoma cells, DNA damage and survival parameters, comparison with V79 cells (human), 113, 278

fast, spontaneous tumors, therapeutic gain factors for fractionated treatment (mouse), 116, 482

fibroblasts, oncogenic transformation by fractionated doses, analysis (mouse), 114, 589; erratum, 116, 550

$-\gamma$ irradiation, whole-body, radioprotection with WR-2721 and/or 16,16-dimethylprostaglandin $\mathrm{E}_{2}$ (mouse), 115, 605

kidney, response to very small doses per fraction, comparison to $\mathrm{X}$ irradiation (mouse), 114, 385

mice, effect of 60 once-weekly exposures, 115, 347

V79 cells, induction of chromosome damage, radioprotective effects of WR-1065, 113, 145

and $X$ irradiation, lens epithelial cells, recovery from single and fractionated doses, comparison (mouse), 114, 567

whole-body, effects of graded doses on stromal compartment of thymus (mouse), 113, 25

\section{Neutrons}

14.6- $\mathrm{MeV}$, carbon kerma factor, calorimetric measurements, correction, 113, 396; reply, 113, 398

Nitrogen mustard, see Mechlorethamine

1 (2 - Nitro - 1 - imidazolyl) - 3 - (1 - aziridinyl $)$ - 2 propanol, see RSU-1069

Nuclear accidents

treatment of victims, role of bone marrow transplantation, 113, 205

Nuclear magnetic resonance

${ }^{31} \mathrm{P}$, in analysis of pentobarbital anesthesia effects on tumor energy metabolism in vivo (mouse), 115, 361

Nuclear power plants

safety in the United States, assessment, 113, 211, 217

Nuclei

abnormal, in renal proximal tubular cells after $\gamma$ irradiation, characterization (mouse), 115, 161
Oligodeoxynucleotides

sugar moiety, $\mathrm{H}$ atom abstraction by thymine radicals, analysis, 116, 210

Oxidation

thiols in CHO cells by SR-4077, 113, 346; erratum, 114, 643

WR-1065, influencing factors, 113, 243

Oxygen

dependence of

cytotoxic and radiosensitizing effects of cisdichlorodiammineplatinum(II) on cervical carcinoma cells in vitro (human), 114, 489

product formation in $\gamma$-irradiated adenosine 5 '-monophosphate solutions, 113, 447

radiosensitivity enhancement by postirradiation hypoxia (hamster, human, murine tumor cells), 116, 124

effect on

delay in initiation of DNA synthesis after irradiation (murine melanoma), 113, 102

induction and repair of DNA damage in $\gamma$-irradiated lymphoblasts (human), 115, 436

radiation-induced inactivation of $\mathrm{r}$-chromatin in vitro, influence of $t$-butanol (Tetrahymena), 115, 141

Oxygen enhancement ratio

colon tumor cells, effects of $\mathrm{N}$-methylformamide and sodium butyrate (human), 113, 191

Oxygen uptake

in brain homogenates, relationship to opposite effects of WR-2721 and WR-1065 on $\gamma$-rayinduced hypothermia (guinea pig), 114, 240

by $\mathrm{CHO}$ and FSa-II cells, inhibition by lonidamine, 113, 356

$\mathbf{P}$

Pentamidine

effect on heat sensitivity of HeLa cells, 116, 320

Pentobarbital

anesthesia, effects on tumor energy metabolism in vivo, analysis by ${ }^{31} \mathrm{P}$ NMR spectroscopy (mouse), 115, 361

effect on tumor blood flow (rat), 114, 64

$\mathrm{pH}$

extracellular

effects on intracellular $\mathrm{pH}$ and cell energy status: relationship to hyperthermic sensitivity (CHO cells), 116, 305

role in acid-induced increase in hyperthermic readionsensitization ( $\mathrm{CHO}$ cells), 115, 576

intracellular

changes in $\mathrm{CHO}$ cells heated at $45^{\circ} \mathrm{C}$ at $\mathrm{pH} 6.6$, 115, 106 
low values, role in $\mathrm{CHO}$ cell sensitization to hyperthermia, 114, 154

relationship to extracellular $\mathrm{pH}$ of $\mathrm{CHO}$ cells heated at $45^{\circ} \mathrm{C}$ at $\mathrm{pH} 6.6,115,96$

role in acid-induced increase in hyperthermic radiosensitization ( $\mathrm{CHO}$ cells), 115, 576

\section{Phosphoinositides}

cellular metabolism, effect of hyperthermia (mammalian cells), 113, 414

\section{Photolysis}

ultraviolet, pyrimidine derivatives in aqueous solutions containing $\mathrm{H}_{2} \mathrm{O}_{2}$, spin-trapping study, 116, 56

\section{Photons}

low-energy, in polyatomic gases, mean energy required for ion pair formation, 115, 213

plus normobaric $\mathrm{O}_{2}$, hyperbaric $\mathrm{O}_{2}$, or misonidazole, in fractionated irradiation of spontaneous tumors, therapeutic gain factors (mouse), 116, 482

Plutonium

particle aggregation in lung after ${ }^{239} \mathrm{PuO}_{2}$ inhalation, promotion of carcinogenesis (rat), 116, 393

${ }^{239} \mathrm{Pu}$, inhalation-induced chronic lung injury, effect on cardiopulmonary function (dog), 115,314

Pneumonitis

$\gamma$-radiation-induced

protective effect of corticosteroids (mouse), 113, 112

replicative activity of alveolar type 2 cells, enhancement by methylprednisolone (mouse), 115, 543

Poly(adenosinediphosphoribose)

synthesis inhibitors, and structurally related compounds, effects on X-irradiation-induced $\mathrm{G}_{2}$ arrest (CHO cells), 113. 58

Poly(ADP-ribose)polymerase, see $\mathrm{NAD}^{+}$ADP-ribosyltransferase

Poly(ADP-ribose)synthetase

role in thermotolerance and heat and radiation responses (V79 cells), 116, 442

Polyamines

$\alpha$-difluoromethylornithine - induced depletion, effects on radiosensitivity of colon carcinoma cells (human), 114, 634

Polydeoxynucleotides

sugar moiety, $\mathrm{H}$ atom abstraction by thymine radicals, analysis, 116, 210

\section{Porfiromycin}

as adjunct to radiotherapy, preclinical studies (murine mammary tumor cells), 116, 100

Potentially lethal damage

$\alpha$ form, arabinofuranosyladenine-mediated fixation in X-irradiated plateau-phase $\mathrm{CHO}$ cells, relationship to chromosome repair, 114, 361

in $\gamma$-ray-sensitive XR-1 cells, cell cycle-dependent repair (Chinese hamster), 115, 325

repair

capacity of fibroblasts in exponential growth phase, correlation with survival curve (human), 116, 74

in $\gamma$-irradiated normal and malignant cells, in vitro analysis (human), 114, 415

and inhibition by hyperthermia in normal hamster cells, mouse cells, and transformed mouse cells, 113, 171

in V79 cells expressible by postirradiation treatment with hypertonic phosphate-buffered saline, analysis, 116, 472

in X-irradiated cerebral gliosarcoma cells grown as monolayers and spheroids, comparison (rat), 114, 515

and sublethal damage

in L5178Y-R and L5178Y-S cells, effects of reduced temperature and starvation conditions, 113, 458

repair in L5178Y lymphoma cells differing in radiation sensitivity (mouse), 113, 183

$\mathrm{X}$-ray-induced, in V79 cells, repair, metabolic effects of cordycepin and 2-halo derivatives, 114, 231

Proadipocytes

uv-irradiation-induced DNA damage, effect of cellular differentiation on repair (mouse), 116, 217

Proliferation

fibrosarcoma cells, kinetics during fractionated ionizing irradiation (mouse), 116, 327

Prostaglandins

role in irradiation-induced temperature responses (rat), 114, 42

Proteins

-DNA crosslinks, repair in $\gamma$-irradiated V79 cells, effects of glutathione depletion and hypoxia, 116, 89

erythrocyte, shedding after microwave irradiation, chromatographic analysis (human), 114, 500

heat-shock, see Heat-shock proteins

Protein synthesis

in lens epithelial cells stimulated from quiescence, sensitivity to $\mathrm{X}$-ray-induced growth arrest (rat), 113, 133

in X-irradiated CHO-tsHI and CHO-SCl cells, analysis, 114, 281

Protons

$0.3-20-\mathrm{MeV}$, track structures obtained by computer simulation, microdosimetric aspects, 115, 389 
Purine ribonucleosides

effect on hyperthermic killing of glucose-deprived hypoxic HeLa cells, 116, 337

Pyrimidine ribonucleosides

effect on hyperthermic killing of glucose-deprived hypoxic HeLa cells, 116, 337

Pyrimidines

derivatives in aqueous solutions, sonolysis, radiolysis, and hydrogen peroxide photolysis: spin-trapping study, 116, 56

dimers, persistent, in DNA of normal and xeroderma pigmentosum fibroblasts, proximity to repair patches, analysis (human), 116, 245 salvage, absence in Escherichia coli thy $A$ cells fed dihydrothymine and thymine glycol, 115, 617

Q

Quality factor

in ionizing radiation, redefinition as function of lineal energy, 114, 480

R

Radiation

exposure responses, thresholds in, guest editorial, 114, 1

galactic cosmic, transport codes, analytic benchmark solution, 114, 201

linear energy transfer, thresholds in exposure responses, letter to editor, 116, 172

low dose-rate exposures, importance of determination of effects, editorial, 116, 1

research, multidisciplinary contributions of the journal, letter to the editor, 114, 198

Radicals, see also specific radicals

carbon- and sulfur-centered, generated in X-irradiated $\mathrm{L}-\alpha$-amino- $n$-butyric acid $\mathrm{HCl}$ containing $1.5 \%$ L-cysteine $\mathrm{HCl}$, ESR study, 116, 373

secondary, formation and reaction mechanisms in X-irradiated single crystals of guanine hydrochloride monohydrate, ESR and ENDOR spectroscopy, 116, 379

Radiobiology

application of microdosimetry, 113, 15

Radiolabeling

DNA with ${ }^{125}$ I, decay calibration for measurement of X-ray-induced double-strand breaks (V79 cells), 115, 624

Radiolysis

aqueous solutions of pyrimidine derivatives, spin-trapping study, 116, 56

pulse, in analysis of radicals produced from methylated uracils via $\mathrm{SO}_{4}{ }^{-}$oxidation, 114 , 207

\section{Radioprotection}

bacteriophages T4 and P22 against $\gamma$ irradiation inactivation, mediation by ergothioneine, histidine, carnosine, and anserine, 114, 319

brain by WR-2721 via entry across modified blood-brain barrier (rat), 115, 303

DNA by thiols, relationship to thiol net charge, 114, 11

emesis, in normal and postremectomized cats at 24 hours after ${ }^{60} \mathrm{Co}$ irradiation, analysis, 114, 77

Escherichia coli by cysteamine, mechanisms, 114,550

hematopoietic stem cells, induction by leukotrienes (mouse), 113, 388

jejunum by WR-2721 and WR-1065 in vivo: effects on DNA strand break induction and rejoining (mouse), 114, 268

mice against neutron- $\gamma$ irradiation with WR2721 and/or 16,16-dimethylprostaglandin $\mathrm{E}_{2}, \mathbf{1 1 5}, 605$

standards, need for good risk estimates, editorial, 116, 1

V79 cells by WR- 1065 after $\gamma$-ray- and fissionspectrum neutron-induced chromosome damage, 113, 145

WR-1065 against $\gamma$-ray-induced DNA singlestrand breaks in CHO cells, 113, 155

\section{Radiosensitivity}

CHO cells, effect of dimethylfumarate, 115, 495

colon tumor cells

changes after exposure to sodium butyrate (human), 114, 579

effects of $\alpha$-difluoromethylornithine-induced polyamine depletion (human), 114, 634

DNA synthesis in lens epithelial cells exposed to $\mathrm{X}$-ray-induced growth arrest after stimulation from quiescence (rat), 113, 133

eukaryotic cells, variation among, effect on repair of DNA double-strand breaks (Trichoplusia $n i, \mathrm{~V} 79$ cells), 113, 268

fibroblasts in exponential growth phase, correlation with potentially lethal damage repair capacity, analysis (human), 116, 74

fibrosarcoma late recurrences after radiotherapy (mouse), 113, 334

hepatocytes, comparison between human and rat, 115, 152

L5178Y lymphoma cells to $\mathrm{X}$ irradiation, repair of potentially lethal damage and sublethal damage (mouse), 113, 183

L5178Y-R and L5178Y-S cells

differences in, role of

DNA and chromosome repair (mouse), 115, 566 
initial DNA and chromosome damage (mouse), 115, 550

effects of reduced temperature and starvation conditions, 113, 458

normal and malignant cells exposed to $\gamma$ rays in vitro, evaluation (human), 114, 415

RIF-1 tumor, effect of etomidate, 114, 105

role of poly(ADP-ribose)synthetase (V79 cells), 116, 442

thymus nonlymphoid components to $\gamma$-ray exposure in vitro, evaluation (dog), 115, 84

tumor cells

assessment techniques, implications for clinical oncology (human), 114, 401

enhancement by postirradiation hypoxia: time course and oxygen concentration dependency (hamster, human, mouse), 116, 124

initial part of survival curve as predictor, evaluation (human), 114, 425

V79 cells

acute uv exposures, alteration by multiple small far- or mid-uv light exposures, measurement by cell lethality and mutagenesis, 114, 248

enhancement by moderate hyperthermia at low ${ }^{137} \mathrm{Cs}$ irradiation dose rates, 114, 379

Radiosensitization

cervical carcinoma cells by cis-dichlorodiammineplatinum(II), in vitro analysis (human), 114,489

CHO cells

by hyperthermia, acid-induced increase, role of intracellular and extracellular $\mathrm{pH}, 115$, 576

by SR-4077, 113, 346; erratum, 114, 643

thymineless, prevention in Escherichia coli thyA cells fed dihydrothymine and thymine glycol, 115, 617

tumors in vivo by diethyldithiocarbamate (mouse), 116, 539

\section{Radiotherapy}

in conjuction with porfiromycin, preclinical studies (murine mammary tumor cells), 116, 100

fractionated, outcome, initial part of survival curve as predictor, evaluation (human), 114, 425

Hodgkin's disease patient, induction of structural chromosome aberrations in peripheral lymphocytes, 114, 528

induced carcinogenesis in patients with cervical cancer: relationship between radiation dose and cancer risk, 116, 3

Radium

${ }^{224} \mathrm{Ra}$, injected patients, incidence of cataracts, epidemiological analysis, 115, 238
${ }^{226} \mathrm{Ra}$, microdistribution and local dosimetry in trabecular bone after iv injection (dog), 116, 263

Recombination

mitotic, in diploid yeast strain after continuous long-term $\gamma$ irradiation, 113, 71

Recovery

AA8 cells and radiosensitive clones after $\gamma$ irradiation, 115, 223

hemopoietic and stromal progenitor cells in $\gamma$-irradiated bone marrow, effect of low dose rate (mouse), 115, 481

split-dose, analysis in X-irradiated CHO-tsH 1 and $\mathrm{CHO}-\mathrm{SCl}$ cells, 114, 281

TN-368 cells after $\gamma$ irradiation, enhancement by split-dose treatment, 115, 413

tumor cells after $\mathrm{X}$ irradiation, effect of $\mathrm{N}$-methylformamide (mouse), 113, 199

Redoxy-endonuclease

mediated DNA cleavage at sites of uv-induced photoproducts, wavelength dependence (human), 113, 543

Relative biological effectiveness

neutron irradiation of

$\mathrm{A}_{\mathrm{L}}$ cells, 115, 281

Repair

mice, 115, 347

chromosomes and DNA after X-ray-induced damage, role in radiosensitivity difference between L5178Y-R and L5178Y-S cells (mouse), 115, 566

DNA double-strand breaks

in eukaryotic cells with different radiosensitivities (Trichoplusia ni, V79 cells), 113, 268

in $\gamma$-ray-sensitive XR-1 cells, dependence on cell cycle phase, 115,325

inhibition by SR-4077 (CHO cells), 113, 346; erratum, 114, 643

DNA lesions in $\gamma$-irradiated lymphoblasts, effects of oxygen and misonidazole (human), 115, 436

long-term in vivo, colony-forming ability and chromosomal injury in $\mathrm{X}$-irradiated hepatocytes (mouse), 113, 40

potentially lethal damage

fibroblasts in exponential growth phase, correlation with survival curve (human), 116, 74

and inhibition by hyperthermia in normal hamster cells, mouse cells, and transformed mouse cells, 113, 171

and sublethal damage

in L5178Y lymphoma cells differing in radiation sensitivity (mouse), 113, 183

in L5178Y-R and L5178Y-S cells, effects of reduced temperature and starvation conditions, 113, 458 
Repair patches

in DNA of normal and xeroderma pigmentosum fibroblasts, proximity to persistent pyrimidine dimers, analysis (human), 116, 245

Resistance

hydrogen peroxide, associated increases in catalase activity (CHO HA-1 cells), 114, 114

Respiration

pulmonary, effect of chronic ${ }^{239} \mathrm{PuO}_{2}$ inhalation exposure (dog), 115, 314

Retina

effect of accelerated argon ions (rat), 115, 192

Risk estimation

as basis for sane radiation protection standards. editorial, 116, 1

radiotherapy-induced carcinogenesis in patients with cervical cancer, evaluation of broad dose range, 116, 3

RNA

synthesis in lens epithelial cells stimulated from quiescence, sensitivity to $\mathrm{X}$-ray-induced growth arrest (rat), 113, 133

RSU-1069

radiosensitization of tumor cells, enhancement by hydralazine-induced hypoxia after $\mathrm{X}$ irradiation (mouse), 115, 292

\section{$S$}

Saline

hypertonic phosphate-buffered, treatment of V79 cells after $\gamma$ or X irradiation: estimation of interaction function $\gamma(x), \mathbf{1 1 6}, 472$

Salivary gland

intracellular free $\mathrm{Ca}^{2+}$ levels, relationship to heat shock-induced protein synthesis and cytoskeletal rearrangements (Drosophila melanogaster), 113, 402

Seminiferous epithelium

spermatogonia

depletion after $\mathrm{X}$ irradiation (rhesus monkey), 113, 473

repopulation after $\mathrm{X}$ irradiation (rhesus monkey), 113, 487

Sensitization

to hyperthermia, role of low intracellular $\mathrm{pH}$ (CHO cells), 114, 154

Serum

copper levels, evaluation as index of lung injury after hemithorax exposure to $\gamma$ rays (rat), 114,613

mitogenic response of $\mathrm{CHO}$ HA- 1 cells after hyperthermic cell killing, 113, 501

starvation, and hyperthermic cell killing, effect on viability of CHO HA-1 cells, 113, 513
Simian virus 40

$\gamma$-irradiated intranuclear DNA, strand breaks, intracellular induction and repair, analysis (CC91, CV-1 cells), 116, 462

Skin

collagen biosynthesis, $\gamma$-ray-induced increases, 48-week study (mouse), 116, 145

healing wounds, physical strength, effect of $\mathrm{X}$ irradiation (mouse), 116, 135

tetrachlorodecaoxide effects after whole-body $\gamma$ irradiation (rat), 115, 115

tumor induction after repeated $\beta$ irradiation in limited dose range, $100 \%$ incidence (mouse), 115,488

Sodium butyrate

effect on

CHO HA-1 cell survival after $\mathrm{X}$ irradiation, 114, 186

oxygen enhancement ratio of colon tumor cells (human), 113, 191

radiosensitivity and glutathione content of colon tumor cells (human), 114, 579

Sonolysis

aqueous solutions of pyrimidine derivatives, spin-trapping study, 116, 56

Spectroscopy

NMR, central nervous system after heavy ion irradiation (rat), 113, 79

Spermatogonia

in seminiferous epithelium

effect of $\mathrm{X}$ irradiation (rhesus monkey), 113 , 473

repopulation after $\mathrm{X}$ irradiation (rhesus monkey), 113, 487

SR-4077

radiosensitization, thiol oxidation, and inhibition of DNA repair (CHO cells), 113, 346; erratum, 114, 643

Stem cells

hematopoietic, leukotriene-induced radioprotection (mouse), 113, 388

hemopoietic and stromal, recovery in bone marrow after $\gamma$ irradiation, effect of low dose rate (mouse), 115, 481

Sublethal damage

and potentially lethal damage

in L5178Y lymphoma cells differing in radiation sensitivity (mouse), 113, 183

in L5178Y-R and L5178Y-S cells, effects of reduced temperature and starvation conditions, 113, 458

repair in $\gamma$-irradiated normal and malignant cells, in vitro analysis (human), 114, 415

Sulfate radicals

oxidation of methylated uracils: production of radicals, pulse radiolytic analysis, 114, 207 


\section{Survival}

AA 8 cells and radiosensitive clones after $\gamma$ irradiation, 115, 223

CHO HA- 1 cells

during serum starvation and hyperthermic cell killing, assessment, 113, 513

after $\mathrm{X}$ irradiation, effects of sodium butyrate and 3-aminobenzamide, 114, 186

L5178Y-R and L5178Y-S cells after X irradiation, relationship to

DNA and chromosome repair (mouse), 115, 566

initial DNA and chromosome damage (mouse), 115, 550

V79 cells after acute exposures, effects of multiple small far- or mid-uv light exposures, 114, 248

\section{Survival curve}

exponential or shouldered, resulting from repair of DNA double-strand breaks, dependence on postirradiation conditions (yeast), 114, 54

fibroblasts in exponential growth phase, correlation with potentially lethal damage repair capacity, analysis (human), 116, 74

initial part, evaluation as predictor of fractionated radiotherapy outcome (human), 114, 425

\section{$\mathbf{T}$}

\section{Temperature}

body, see Body temperature

dependence of cytotoxic and radiosensitizing effects of cis-dichlorodiammineplatinum(II) on cervical carcinoma cells in vitro (human), 114, 489

Tetrachlorodecaoxide

regenerative effects after whole-body $\gamma$ irradiation (rat), 115, 115

Therapeutic gain factors

for fractionated irradiation of spontaneous tumors with with fast neutrons, photons plus $\mathrm{O}_{2} !$ or $3 \mathrm{ATA}$, or photons plus misonidazole (mouse), 116, 482

Thermoresistance

Chinese hamster lung and Morris hepatoma cells, role of hyperthermia-induced $\mathrm{Ca}^{2+}$-dependent cellular responses, 113, 426

Thermosensitivity

and mitochondrial glutathione depletion, relationship (CHO cells), 115, 461

Thermotolerance

defective mutants, isolation and characterization (CHO cells), 113, 526 development in $\mathrm{CHO}$ cells heated at $45^{\circ} \mathrm{C}$ at $\mathrm{pH} 6.6,115,106$

after microinjection with glutathione disulfide,

115,202

preirradiated intestine, effect on time-temperature relationships (mouse), 113, 375

role of poly(ADP-ribose)synthetase (V79 cells), 116, 442

Thiobutabarbital

effect on tumor blood flow (rat), 114, 64

Thiols

low-molecular-weight, interaction with DNA: evidence for counterion condensation and coion depletion near DNA, 114, 3

net charge and radioprotection of DNA, relationship, 114, 11

Thresholds

in radiation exposure responses, guest editorial, 114, 1

Thymine glycol

effect on pyrimidine salvage and thymineless radiosensitization in Escherichia coli thy A cells, 115, 617

Thymine radicals

abstraction of $\mathrm{H}$ atom from sugar moiety in oligo- and polydeoxynucleotides, analysis, 116, 210

Thymus

microwave irradiation, effect on cellular functional state (rabbit), 115, 44

nonlymphoid components, effects of $\gamma$ irradiation in vitro $(\mathrm{dog}), 115,84$

stromal compartment, effects of graded doses of whole-body neutron and $\mathrm{X}$ irradiation (mouse), 113, 25

Track structures

high-LET particles, linear simulations: frequency distributions and density functions of distances, 113, 437

$0.3-20-\mathrm{MeV}$ protons, obtained by computer simulations, microdosimetric aspects, 115, 389

Transformation

oncogenic, fibroblasts by fractionated doses of neutrons, analysis (mouse), 114, 589; erratum, 116, 550

Transplants

bone marrow, role in treatment of victims of nuclear accidents, 113, 205

Transport codes

galactic cosmic-ray, analytic benchmark solution, 114, 201

Transposons

induced chromosome damage, interaction with $\mathrm{X}$-ray-induced damage: translocations and 
transmission distortion (Drosophila melanogaster), 115, 503

Tumor bed effect

associated tissue repair and repopulation, analysis (mouse), 114, 621

induced environmental stress, associated cell subpopulation exclusion within heterogeneous neoplasms: mathematical models, 115,533

Tumor cells, see also Cell lines

brain, sister chromatid exchange, additive induction by $\mathrm{X}$ rays and 1,3-bis(2-chloroethyl)-1nitrosourea (rat), 115, 187

cerebral gliosarcoma, grown as monolayers and spheroids, repair of potentially lethal damage and reentry into cycling phase after $X$ irradiation, comparison (rat), 114, 515

cervical carcinoma

with differing radiosensitivity, DNA doublestrand breaks, induction and rejoining after $\gamma$ irradiation (human), 116, 526

oxygen- and temperature-dependent cytotoxic and radiosensitizing effects of cis-dichlorodiammineplatinum(II) in vitro (human), 114, 489

colon

oxygen enhancement ratio, effects of $\mathrm{N}$-methylformamide and sodium butyrate (human), 113, 191

radiosensitivity

effects of $\alpha$-difluoromethylornithine-induced polyamine depletion (human), 114, 634

and glutathione content, changes after exposure to sodium butyrate (human), 114, 579

DS-carcinosarcoma, blood flow, effects of inhalational or injectable anesthetics and of neuroleptic, neuroleptanalgesic, and sedative agents (rat), 114, 64

epithelial teratocarcinoma, radiobiological characterization, DNA damage, and comparison with other rodent and human cell lines, 113, 278

fibrosarcoma

changes in bromodeoxyuridine labeling index during radiation treatment (mouse), 116, 453

energy metabolism, effects of pentobarbital anesthesia, analysis by in vivo ${ }^{31} \mathrm{P}$ NMR spectroscopy (mouse), 115, 361

inoculation into $\gamma$-irradiated hind thigh: tissue repair and repopulation in tumor bed effect (mouse), 114, 621 late recurrences, radiosensitivity after radiotherapy (mouse), 113, 334

oxygen uptake, inhibition by lonidamine (mouse), 113, 356

proliferation kinetics during fractionated ionizing irradiation (mouse), 116, 327

radiocurability, effect of $N$-methylformamide (mouse), 113, 199

glioma, mass blood flow changes after cerebral $\gamma$ irradiation (rat), 115, 586

heterogeneous, tumor bed effect-induced environmental stress, associated cell subpopulation exclusion: mathematical models, 115, 533

leukemia, mutation induction by very low dose rate $\gamma$ irradiation (mouse), 115, 273

Lewis lung carcinoma, blood flow reduction by hydralazine after $\mathrm{X}$ irradiation, effect on efficacy of misonidazole and RSU-1069 (mouse), 115, 292

lymphoma, strains differing in radiation sensitivity, repair of potentially lethal damage and sublethal damage (mouse), 113, 183

mammary

cell cycle effect on X-ray-induced DNA double- and single-strand breaks, comparison (mouse), 116, 228

EMT6, response to $X$ irradiation, effects of porfiromycin (mouse), 116, 100

energy metabolism, effects of pentobarbital anesthesia, analysis by in vivo ${ }^{31} \mathrm{P}$ NMR spectroscopy (mouse), 115, 361

radiocurability, effect of $N$-methylformamide (mouse), 113, 199

toxic effects of acute glutathione depletion by L-buthionine sulfoximine and dimethylfumarate (mouse), 114, 215

melanoma

delay in initiation of DNA synthesis after irradiation, effect of oxygen (mouse), 113, 102

lung metastases and lysis by natural killer cells, comparative effects of daily and weekly fractions of X irradiation (mouse), 114, 354

Morris hepatoma, thermoresistance, role of hyperthermia-induced $\mathrm{Ca}^{2+}$-dependent cellular responses, 113, 426

neuroblastoma, synchronized, proliferation after heat treatment, role of heat-shock proteins (mouse), 113, 252

ovarian, induction in $\mathrm{BC} 3 \mathrm{~F}_{1}$ mouse after low dose neutron and $X$ irradiation, 113, 362

pheochromocytoma, intracellular $\mathrm{Ca}^{2+}$ levels and inositol lipid metabolism, effects of hyperthermia (rat), 113, 414 
pulmonary, DNA strand breaks and $1-\beta$-D-arabinofuranosylcytosine-detectable sites induced by $\mathrm{X}$ and $\gamma$ irradiation, comparison (human), 114, 168

radiosensitivity, chemosensitivity, and inherent factors, assessment techniques, implications for clinical oncology (human), 114, 401

rhabdomyosarcoma, radiosensitization in vivo by diethyldithiocarbamate (mouse), 116, 539

RIF-1

killing with 8-hydroxyquinoline, evaluation (mouse), 115, 373

treatment with etomidate and Gibbs clip, evaluation (mouse), 114, 105

skin, induction after repeated $\beta$ irradiation in limited dose range, $100 \%$ incidence (mouse), 115,488

survival curve, initial part, evaluation as predictor of fractionated radiotherapy outcome (human), 114, 425

various types

fractionated irradiation with fast neutrons, photons plus $\mathrm{O}_{2} 1$ or 3 ATA, or photons plus misonidazole, therapeutic gain factors (mouse), 116, 482

radiosensitivity, enhancement by postirradiation hypoxia: time course and oxygen concentration dependency (human, mouse), 116, 124

response to $\gamma$ irradiation, in vitro analysis (human), 114, 415

U

\section{Ultraviolet irradiation}

DNA

subsequent cleavage by Micrococcus luteus $\gamma$ endonuclease, analysis, 114, 556

wavelength dependence of redoxy-endonuclease-mediated cleavage at photoproduct formation sites (human), 113, 543

fibroblasts at solar wavelengths, induction of DNA single-strand breaks, analysis (human skin), 116, 313

proadipocytes, induced DNA damage, effect of cellular differentiation on repair (mouse), 116, 217

V79 cells, sensitivity to acute exposures, alteration by multiple small far- or mid-uv light exposures, measurement by cell lethality and mutagenesis, 114, 248

wild-type eukaryotes and Escherichia coli, comparative action spectra $(254-320 \mathrm{~nm}), 114$, 307 and $\mathrm{X}$ irradiation, quantitative aspects of interactive killing effects in bacteria, 115, 124

Uracils

methylated, radicals produced via $\mathrm{SO}_{4}^{-}$oxidation, pulse radiolytic analysis, 114, 207

Urethan

effect on tumor blood flow (rat), 114, 64

\section{V}

V79 cells

$\gamma$-ray- and fission-spectrum neutron-induced chromosome damage, radioprotective effects of WR-1065, 113, 145

radiobiological characterization, DNA damage, and comparison with human epithelial teratocarcinoma cells, 113, 278

radiosensitivity

and DNA double-strand break repair, comparison, 113, 268

enhancement by postirradiation hypoxia: time course and oxygen concentration dependency, 116, 124

repair of radiation-induced chromatin damage, effects of glutathione depletion and hypoxia, 116, 89

sensitivity to $N$-methyl- $N^{\prime}$-nitro- $N$-nitrosoguanidine, effect of $\gamma$ preirradiation, 115, 609

sequential exposures to high- and low-LET radiations: damage interaction effects as function of cell cycle stage, 115,54

thermotolerance and radiation and heat responses, role of poly(ADP-ribose)synthetase, 116, 442

treated with hypertonic phosphate-buffered saline after $\gamma$ or $\mathrm{X}$ irradiation, interaction function $\gamma(x)$ estimation, 116, 472

$X$ irradiation, lethal effects, modulation by caffeine, 115, 176

$\mathrm{X}$-ray-induced DNA double-strand breaks, measurement by neutral filter elution: calibration by ${ }^{125}$ I decay, 115, 624

\section{W}

Water

condensed, absolute scattering probabilities for subexcitation electrons, determination, 114 , 467

electron-pulsed ice, red luminescence emission, 115,403

Wavelength

uv irradiation, role in redoxy-endonuclease-mediated DNA cleavage at photoproduct formation sites (human), 113, 543 
Wound healing

skin, effect of X irradiation (mouse), 116, 135

WR-1065

oxidation, influencing factors, 113, 243

radioprotective effects on

$\gamma$-ray- and fission-spectrum neutron-induced chromosome damage (V79 cells), 113, 145

$\gamma$-ray-induced DNA single-strand breaks in CHO cells, 113, 155

jejunum, in vivo effects on DNA strand break induction and rejoining (mouse), 114, 268

and WR-2721, opposite effects on $\gamma$-ray-induced hypothermia, correlation with oxygen uptake (guinea pig), 114, 240

WR-2721

and/or 16,16-dimethylprostaglandin $E_{2}$, radioprotection against fission neutron- $\gamma$ irradiation (mouse), 115, 605

effects on X-ray-induced changes in collagen isotypes I, III, and IV (murine lung), 115, 515

entry into brain across modified blood-brain bar$\operatorname{rier}(\mathrm{rat}), \mathbf{1 1 5}, 303$

radioprotection of jejunum, in vivo effects on DNA strand break induction and rejoining (mouse), 114, 268

and WR-1065, opposite effects on $\gamma$-ray-induced hypothermia: correlation with oxygen uptake, analysis (guinea pig), 114, 240

\section{$x$}

\section{$\mathrm{X}$ irradiation}

$\mathrm{L}$ - $\alpha$-amino- $n$-butyric acid $\mathrm{HCl}$ containing $1.5 \%$ $\mathrm{L}$-cysteine $\mathrm{HCl}, \mathrm{ESR}$ study of generated radicals, 116, 373

$\mathrm{BC} 3 \mathrm{~F}$, mouse at low dosage, tumor induction and life-shortening, 113, 362

brain

induced alterations of neuronal chromatic structure in cerebellum, analysis (rat), 114, 94

tumor cells, and treatment with 1,3-bis(2chloroethyl)-1-nitrosourea, additive induction of sister chromatid exchange (rat), 115 , 187

cerebral gliosarcoma cells grown as monolayers and spheroids, subsequent repair of potentially lethal damage and reentry into cycling phase, comparison (rat), 114, 515

cervical carcinoma cells in vitro: oxygen- and temperature-dependent cytotoxic and radiosensitizing effects of cis-dichlorodiammineplatinum(II) (human), 114, 489
$\mathrm{CHO}$ cells

HA-1, subsequent survival, effects of sodium butyrate and 3-aminobenzamide (Chinese hamster), 114, 186

induced $\mathrm{G}_{2}$ arrest, effects of poly(adenosinediphosphoribose) synthesis inhibitors and structurally related compounds, 113,58

sensitivity, effect of dimethylfumarate, 115, 495

CHO-tsH1 and $\mathrm{CHO}-\mathrm{SCl}$ cells, protein synthesis and split-dose recovery, 114, 281

colon tumor cells

changes in radiosensitivity after exposure to sodium butyrate (human), 114, 579

oxygen enhancement ratio, effects of $N$-methylformamide and sodium butyrate (human), 113, 191

dose fractionation, sensitivity of hepatocyte clonogens (mouse), 113, 51

Drosophila melanogaster, induced chromosome damage, interaction with transposon-induced damage: translocations and transmission distortion, 115, 503

epithelial teratocarcinoma cells, DNA damage and survival parameters, comparison with V79 cells (human), 113, 278

guanine hydrochloride monohydrate single crystals, formation of secondary radicals, reaction mechanisms, ESR and ENDOR spectroscopy, 116, 379

guanosine 5 '-monophosphate single crystals at $10^{\circ} \mathrm{K}, \mathrm{ESR} / \mathrm{ENDOR}$ study, 116, 196

hepatocytes, long-term repair in vivo of colonyforming ability and chromosomal injury, analysis (mouse), 113, 40

Hodgkin's disease patient, induction of structural chromosome aberrations in peripheral lymphocytes, 114, 528

human cell lines, induction of DNA strand breaks and 1- $\beta$-D-arabinofuranosylcytosine detectable sites, 114, 168

intestine, and hyperthermia, induction of thermotolerance, effect on time-temperature relationships (mouse), 113, 375

kidney, response to very small doses per fraction, comparison to neutron irradiation (mouse), 114,385

lens epithelial cells, sensitivity to induction of growth arrest after stimulation from quiescence (rat), 113, 133

Lewis lung carcinoma, subsequent blood flow reduction by hydralazine, effect on efficacy of misonidazole and RSU-1069 (mouse), 115, 292 
limb, induced carcinogenesis, effect of hyperthermia (mouse), 115, 448

lung, changes in collagen isotypes I, III, and IV, effects of time, dose, and WR-2721 (mouse), 115, 515

L5178Y lymphoma cell strains differing in radiation sensitivity, repair of potentially lethal damage and sublethal damage (mouse), 113, 183

L5178Y-R and L5178Y-S cells, difference in radiosensitivity, role of

DNA and chromosome repair (mouse), 115, 566

initial DNA and chromosome damage (mouse), 115, 550

mammary tumor cells

effects of porfiromycin (mouse), 116, 100

induced DNA double- and single-strand breaks, cell cycle effects, comparison (mouse), 116, 228

mice

effect on physical strength of healing skin wounds, 116, 135

inoculated with $\mathrm{B} 16_{\mathrm{a}}$ melanoma, effects of daily and weekly fractions on lung metastases and natural killer cell activity, 114, 354

and neutron irradiation, lens epithelial cells, recovery from single and fractionated doses, comparison (mouse), 114, 567

normal hamster cells, mouse cells, and transformed mouse cells, repair of potentially lethal damage, inhibition by hyperthermia, 113, 171

plateau-phase $\mathrm{CHO}$ cells, induced chromosome damage, effect of arabinofuranosyladenine: implications for repair and fixation of $\alpha$-potentially lethal damage, 114, 361

preimplantation embryos, induction of nonlethal changes, assay with embryo aggregation chimeras (mouse), 113, 289

prenatal, effects on appearance of reflexes and physiological markers (rat), 116, 416

rhabdomyosarcoma in vivo, radiosensitization by diethyldithiocarbamate (mouse), 116, 539

RIF-1 tumors, combined with 8-hydroxyquinoline treatment, in tumor-targeted cell killing, evaluation (mouse), 115, 373

seminiferous epithelium

depletion of spermatogonia (rhesus monkey), 113, 473 subsequent repopulation of spermatogonia (rhesus monkey), 113, 487

total lymphoid, late somatic effects (mouse), 116, 503

tumor cells, radiosensitivity enhancement by postirradiation hypoxia: time course and oxygen concentration dependency (hamster, human, mouse), 116, 124

and uv irradiation or nitrogen mustard treatment, quantitative aspects of interactive killing effects in bacteria, 115, 124

V79 cells

combination with exposure to argon and neon ions: damage interaction effects as function of cell cycle stage, 115,54

induced DNA double-strand breaks, measurement by neutral filter elution: calibration by ${ }^{125}$ I decay, 115, 624

induced potentially lethal damage, repair, metabolic effects of cordycepin and 2-halo clerivatives, 114, 231

lethal effects, modulation by caffeine, 115, 176 and treatment with hypertonic phosphatebuffered saline: estimation of interaction function $\gamma(x), 116,472$

whole-body, effect of graded doses on strromal compartment of thymus (mouse), 11 3., 25

Xeroderma pigmentosum

fibroblasts from patients, and normal fibrobblasts, DNA, proximity of repair patches to persisXylazine tent pyrimidine dimers, analysis, 116, .245

with ketamine, effect on tumor blood flow' (rat), 114,64

Y

Yeast

mutant rad54-3, repair of DNA double:-sstrand breaks, resultant exponential or shoulidered survival curves, dependence on postirrradiation conditions, 114, 54

Saccharomyces cerevisiae, diploid strain, mitotic recombination after continuous long-teerm $\gamma$ irradiation, 113, 71

Z

Zacopride

effects on $\gamma$ radiation-induced emesis (r rhesus monkey), 115, 595 